\title{
Hermeto Pascoal: experiência de vida e a formação de sua linguagem harmônica
}

\author{
Fausto Borém (UFMG, Belo Horizonte, MG) \\ fborem@ufmg.br \\ Fabiano Araújo (UFES, Vitória, ES) \\ armoniah@gmail.com
}

Resumo: Estudo panorâmico sobre a trajetória musical e a formação das linguagens harmônicas do compositor, arranjador e multi-instrumentista Hermeto Pascoal ao longo de suas fases musicais, linguagens que são geralmente associadas, na música erudita, ao tonalismo, modalismo, atonalismo, polimodalismo, paisagem sonora e música concreta. São observados como elementos de sua experiência de vida (cultural, social, religiosa e profissional) podem ter influenciado a combinação vertical de sons na sua criação musical, bem como a sua proposta e utilização de conceitos como música universal, cifragem universal, música da aura, música dos ferros e método do corpo presente.

Palavras-chave: Hermeto Pascoal; música popular brasileira; etnomusicologia brasileira; harmonia; análise musical; auto-didatismo em música.

\section{Hermeto Pascoal: life experience and the formation of his harmonic language}

\begin{abstract}
Panoramic study about the musical trajectory and development of the harmonic languages of the Brazilian composer, arranger e multi-instrumentalist Hermeto Pascoal through his musical phases, languages which are usually associated with the "classical" terms tonalism, modalism, atonalism, polimodalism, soundscape and concrete music. It is observed how elements of his life experience (cultural, social, religious and professional) may have influenced the vertical combination of sounds in his musical output as well as his proposition and usage of concepts such as universal music, universal chord notation, aura music, iron scraps music and present-body method.
\end{abstract}

Keywords: Hermeto Pascoal; Brazilian popular music, Brazilian ethnomusicology; harmony; musical analysis; autodidacticism in music.

\author{
"Eu uso a teoria, a teoria não me usa. .." \\ Hermeto Pascoal (CAVALCANTI, 2004)
}

\section{1 - Introdução}

Este estudo panorâmico tem o objetivo de apresentar a formação da linguagem harmônica na trajetória musical de Hermeto Pascoal. Conhecer o percurso não-convencional de sua formação nos mostra como surgem, se acomodam e se integram, dentro da sua obra, as diversas nuances de sua linguagem harmônica, que tem sido associada, na música erudita, aos termos tonalismo, modalismo, atonalismo, polimodalismo, paisagem sonora e música concreta.

0 conjunto de 366 peças do Calendário do som, bem como a maioria de sua vasta produção, se associa à música tonal. Entretanto, os procedimentos peculiares de Hermeto (músico de formação intuitiva, não letrada) de se afastar e de se aproximar dos centros tonais em cada uma delas, assim como sua grafia especial de cifras (que explicita a condução de vozes), podem revelar um pensamento estruturado que, se nasceram de sua intuição e autodidatismo brasileiros, encontram eco e explicação nos princípios sistematizados por outro importante compositor do século XX, o europeu Arnold Schoenberg (músico de formação erudita, racional, mas autodidata como Hermeto Pascoal).

Ao desenvolver o princípio da Monotonalidade (ou seja, a manutenção de apenas uma tônica em uma peça ou porções significativas da mesma) e seus conceitos relacionados (Tonalidade Expandida, Tonalidade Flutuante, Tonalidade Suspensa, Transformação, Substituição, Regiões, Regiões Intermediárias, Acordes Vagantes), SCHOENBERG (2004, 2001, 1999) buscou simplificar as explicações para os crescentes afastamentos harmônicos proporcionados 
por notas alteradas estranhas à tonalidade inicial. Esta perspectiva inovadora foi aproveitada, no Brasil, por Paulo José TINÉ (2002) dentro do contexto do ensino da música popular, cujo repertório e práticas de performance quase sempre evitam os conceitos de modulação, politonalidade e atonalismo.

Hermeto Pascoal e sua obra constituem um rico manancial de temas de estudo, e proveria temas para diversas áreas de pesquisa em música: composição, performance, etnomusicologia, educação musical, organologia, música e tecnologia, sociologia e psicologia da música. Entre os trabalhos acadêmicos sobre o compositor, destacam-se sete dissertações de mestrado, em que a trajetória musical de Hermeto Pascoal serve de contexto para focos diversos. Entretanto, ainda há uma grande dificuldade de obtenção de fontes consolidadas e atualizadas sobre esse tema. PRANDINI (1996) concentrou seu estudo nos elementos rítmicos, harmônicos e melódicos característicos em improvisações que transcreveu de gravações de Hermeto Pascoal. TABORDA (1998) busca explicar a obra de quatro músicos populares brasileiros (Hermeto Pascoal, Caetano Veloso, Jards Macalé e Chico Mello) com base em matrizes eruditas europeias. K. RODRIGUES (2006) analisou o pianista Hermeto Pascoal juntamente com mais sete outros destacados pianistas da música popular brasileira. ARAÚJO (2006), procurando avançar a proposta de TINÉ (2002), desenvolveu um modelo de análise harmônica aplicado à realização de leadsheets de peças selecionadas do Calendário do som, a partir de conceitos harmônicos de Schoenberg (sistematizados e discutidos por DUDEQUE, 2006), explicando a manutenção e afastamento de centros tonais na música de Hermeto. Dentro do viés da semiologia, ARRAIS (2006) focou em aspectos do ritmo, timbre e contorno melódico. A maioria das informações históricas nestes estudos quase sempre parte de artigos divulgados pela mídia, muitas vezes conflitantes. Neste cenário, Luiz Costa-Lima Neto e Lúcia Campos são exceções, pois oferecem discussões substanciadas em fontes etnomusicológicas primárias, entrevistas com 0 próprio compositor e seus parceiros em grupos diversos. Luiz COSTA-LIMA NETO (1999) estudou a caracterização de elementos rítmicos, harmônicos, melódicos e timbrísticos no período de Hermeto pascoal e Grupo (1981-1993). Lúcia CAMPOS (2006) abordou a influência do forró, choro e bandas de pífanos na rítmica do compositor. Luiz COSTA-LIMA NETO (2000, 2008, 2010a, 2010b) se destaca como o autor que mais publicou trabalhos sobre a vida e obra de Hermeto Pascoal em periódicos no Brasil e no exterior (veja seu artigo 0 cantor Hermeto Pascoal: a voz como instrumento neste número de Per Musi às p.44-62).

É grande o número de discrepâncias em relação a datas, nomes de pessoas, músicas e lugares a respeito de Hermeto Pascoal. 0 site oficial do compositor informa que o escritor baiano Roberto Torres ". . . está escrevendo a biografia do Hermeto há mais de 20 anos.... Ao que tudo indica, Torres, que seria ". . . o pesquisador que mais conhecimento de causa tem a respeito da vida e obra do Hermeto" (MORE-
NA, Aline e PASCOAL, Hermeto, 2009b), ainda não terminou este trabalho. No mesmo site, encontra-se também uma errata de duas páginas (provida por Aline Morena e pelo próprio Hermeto Pascoal) sobre outra fonte importante: o livro para crianças O Menino Sinhô, vida e música de Hermeto Pascoal para crianças (VILLAÇA, 2007). Agradecemos a Hermeto Pascoal, Aline Moreno, Jovino Santos Neto e Itiberê Zwarg por terem generosamente revisado as informações históricas deste artigo.

Grosso modo e quase cronologicamente, a trajetória musical de Hermeto Pascoal pode ser dividida em oito fases:

I (1936-1942): do nascimento à idade escolar, periodo de atenção e familiarização com sons de animais, melodias da fala, objetos, instrumentos musicais e festas do interior em Lagoa da Canoa (Alagoas).

II (1943-1949): da infância à adolescência, periodo de prática instrumental e trabalho informal como músico (fole de oito baixos/pandeiro) em Lagoa da Canoa e adjacências.

III (1950-1957): migração para grandes cidades do Nordeste (Recife, Caruaru, João Pessoa), consolidação profissional (sanfona/pandeiro) e experimentação com o piano.

IV (1958-1968): migração para grandes centros do Sudeste (Rio de Janeiro e São Paulo), mudança do foco de sanfoneiro de regional para pianista de grupos instrumentais, desenvolvimento como compositor e multi-instrumentista e experiência em festivais da canção.

V (1969-1977): viagens aos Estados Unidos, gravações como solista, consolidação internacional como compositor, arranjador e multi-instrumentista.

VI (1978-1993): consolidação da Escola Jabour com Hermeto Pascoal e Grupo, desenvolvimento da notação musical, experiência com gravadoras de pequeno porte.

VII (1994-2002): socialização da Escola Jabour, projetos musicais isolados, como a escrita do Calendário do som, shows nacionais e internacionais com outros solistas e grupos.

VIII (2003-presente): parceria com Aline Morena e formação do duo multi-instrumentista Chimarrão com $R a-$ padura, rompimento com as grandes gravadoras multinacionais e projeto de socialização da obra de Hermeto Pascoal na internet (partituras, textos, vídeos e gravações), shows com seu duo, grupo e big bands.

Quando não indicadas por citação, as informações históricas incluídas neste artigo resultam de um cruzamento e concordância de dados das seguintes fontes: PASCOAL (2009a, 2009b, 2009c), MORENA e PASCOAL (2009a, 2009b, 2009c, 2009d), SIXPACK (2009), COSTA-LIMA NETO (1999, 2000, 2008, 2010a, 2010b), VILLAÇA (2007), CAMPOS (2006), PRADINES (2006) e MARCONDES (1998). 


\section{2- A trajetória musical eclética de Hermeto Pascoal}

"A minha música começou no meu cordão umbilical. Foi quando eu nasci, o meu primeiro som foi esse. .." Hermeto Pascoal (BARROSO, 2009)

Hermeto Pascoal nasceu em 22 de Junho de 1936 no sítio Olho d'Água em Lagoa da Canoa, no município alagoano de Arapiraca, "filho de agricultores [Pascoal José da Costa - ou Seu Pascoal, e Vergelina Eulália de Oliveira - ou Dona Divina], albino e de olho virado" (0. RODRIGUES, 2003). Por parecer um pequeno homenzinho, recebeu da família o carinhoso apelido de Sinhô (VILLAÇA, 2007, p.5-7). Logo se familiarizou com os sons que o rodeavam e vinham de fontes diversas: o fole do pai, os músicos Vicente Cego e Juvenal Tatu que vinham tocar no bar do pai, as sobras de ferro do avô ferreiro Sena da Bolacha, os animais, o sino da igreja, as festas e cantos populares de Lagoa da Canoa, os gritos dos vendedores na feira da vizinha Arapiraca (VILLAÇA, 2007, p.8-25). Aos sete anos, iniciou-se no fole de oito baixos, sem teclado, apenas com botões, também conhecido como harmônico ou péde-bode, pela simplicidade. Mas uma simplicidade dentro da qual Hermeto já vislumbrava combinações pouco usuais. Esse oito baixos em Dó de seu pai era essencialmente diatônico, mas incluía um Fá sustenido, segundo relata Hermeto em uma entrevista a Álvaro CAVALCANTI (2004, CD 4; ouça a faixa única entre 7':48" e 8':05"). Seu Pascoal se animou, ao ver o talentoso filho tocando escondido seu fole, ". . . você vai agora é tocar, papai vai comprar um para você, eu vou vender aí uma vaca, um boi, para comprar um bonito para você" (BARROSO, 2009). Do universo musical de sua infância, também faziam partes as flautas (pifes) de talo de mamona (carrapateira). Aos 11, com apoio da família, formou a dupla Os Galegos do Pascoal com o irmão Zé Neto, também albino, revezando fole e pandeiro em bailes da região (VILLAÇA, 2007, p.26).

No início de sua carreira profissional, Hermeto Pascoal percorreu um caminho ligado à prática de música ao vivo nas rádios. Os Galegos do Pascoal mudaram-se para o Recife em 1950, onde foram contratados pela Rádio Tamandaré. Conheceram Sivuca, que sentiu em Hermeto ". . . ainda de calças curtas. . . 'o fogo sagrado' " (SIVUCA, 2000) e o ajudou a ingressar na Rádio Jornal do Commercio, onde seu irmão já estava. Juntos, os três formaram o trio 0 Mundo Pegando Fogo, nome imposto pelo produtor da rádio Amarílio Niceias e referência à cor rosada e cabelos avermelhados dos três albinos; no trio foi também imposto a Hermeto o apelido de "Sivuquinha". $\mathrm{Na}$ estreia do grupo no Largo da Paz, sem ensaio e com instrumentos novos que Hermeto e Zé Neto mal conheciam (sanfonas de 80 e 120 baixos, ao invés do fole de 8!), o grupo agradou, até o momento em que o locutor pediu Vassourinha. Não conhecer o clássico do frevo em Recife foi fatal, apesar da tentativa de Sivuca, que antes de morrer considerou Hermeto "o Beethoven do século XX" (SIVUCA, 2000), de Ihes salvar a pele. Hermeto foi obrigado, então, a tocar pandeiro na rádio. No progra- ma ao ar livre A Felicidade bate à sua porta, Jackson do Pandeiro lhe deu um conselho: "Hesmeto [Jackson não conseguia falar Hermeto], se você ficar nesse negócio de tocar pandeiro, você não vai pra frente não. Não vê eu, estou começando a cantar, não vou ficar no pandeiro toda hora não". (BARROSO, 2009). Resultado: suspenso do trabalho por quinze dias, por não aceitar tocar apenas pandeiro e ser chamado de "Sivuquinha", Hermeto foi enviado para a rádio de Caruaru e, Zé Neto, para a rádio de Garanhuns, para recomeçarem da estaca zero (VILLAÇA, 2007, p.36-37). 0 maestro Giusepe Mastroianni da Rádio Difusora de Caruaru percebeu que o jovem talento tinha ouvido absoluto, o que levou Hermeto a procurar a escola de música do maestro e violinista Laranjeiras. Mas deste ouviu que não poderia aprender música ali devido à sua deficiência visual, ao que respondeu: "Maestro, eu não preciso das aulas para aprender música. Música eu já sei. Vim até aqui para aprender como é que se escreve a música!" e logo decidiu que "Música não é para ver. Música é para sentir. Se eu deixar de tocar só porque não consigo ler as notas no papel, eu tô é frito!" (VILLAÇA, 2007, p.4243). Mas pediu ao amigo Zé Gomes que Ihe comprasse um livro de música, o Método para Acordeon do carioca Alencar Terra onde, pela primeira vez e aos dezesseis anos, em meio ao oceano desconhecido de símbolos musicais, viu "aquela bola branca, quatro tempos. . . aquela hastezinha. . . a mínima pretinha. ... Aí, deixou de lado esta aprendizagem, pelo menos por um tempo, porque aquela ". . . teoria ia me atrapalhar" (BARROSO, 2009).

Zé Neto mudou-se para o Rio de Janeiro a convite de Luiz Gonzaga. Hermeto, aos 19 anos, retorna ao Recife, onde passa a tocar sanfona no regional de choro da Rádio Jornal do Commercio. No ambiente das rádios, podia assistir aos ensaios de grupos orquestrais com os maestros Guerra-Peixe, Clóvis Pereira, Duda e Joaquim Augusto. Com o convite do guitarrista Heraldo do Monte para trabalhar na Boate Delfim Verde, transfere sua técnica da sanfona para o piano e aprende a tocar "jazz para americano ouvir. . [para] marinheiros da base militar americana" (VILLAÇA, 2007, p.48-49). Ainda no Recife, tocou no regional de Romualdo Miranda, cuja filha Ilza tornou-se sua esposa em 1954, com quem viveu 46 anos e teve seis filhos: Jorge, Fábio (músico multi-instrumentista como o pai), Flávia, Fátima, Fabíula [escrito assim mesmo!] e Flávio. Aceitando o convite de trabalhar no regional da Rádio Tabajara em João Pessoa, Hermeto teve contato com diversos gêneros musicais - "bossa-nova, rock-and-roll, samba-jazz" (VILLAÇA, 2007, p.51), começou a compor e construiu uma grande reputação na Paraiba, mesmo sem saber ler música. Atraído pela efervescência musical do sudeste do Brasil, mudou-se para o Rio em 1958, para tocar sanfona com Pernambuco do Pandeiro em rádios. Na década de 1960, em meio aos festivais da canção, viu surgir a Bossa Nova, a Jovem Guarda, as canções de protesto e 0 Tropicalismo. Embora não se alinhe a nenhum destes movimentos, Hermeto parece ter se identificado com aquele que é considerado o mais sofisticado harmonicamente, o que o levou a ser incluído no time de instrumentistas 
"herdeiros ou continuadores (muitas vezes sobreviventes) da linhagem da bossa-nova" por Ana Maria BAHIANA (1979-1980b, p.77). Para estudar o piano, instrumento caro e trancado a "sete chaves", mas que fazia parte do instrumental básico das rádios e boates, Hermeto contou com o "jeitinho brasileiro" de Heraldo do Monte na Boate Delfim (VILLAÇA, 2007, p.49) e de Pernambuco do Pandeiro na Rádio Mauá (CAMPOS, 2006, p.83).

No Rio de Janeiro, Hermeto logo expandiu sua cultura musical tanto na música instrumental quanto acompanhando cantores em boates, como a Chicote. Tocou piano no conjunto e na boate do violinista Fafá Lemos. Substiuindo o acordeonista Chiquinho do Acordeom, fez parte, brevemente, do Trio Surdina com Fafá Lemos e o violonista Garoto. Depois, participou do conjunto do maestro, flautista e saxofonista Copinha no Hotel Excelsior. Em 1961, mudou-se para São Paulo onde, em 1964, a convite de Airto Moreira, com o fim do Sambalança Trio (que tinha o pianista César Camargo Mariano), fundou o Sambrasa Trio (ROBINSON, 2000). Além de tocar em casas noturnas como Stardust, sempre atento e autodidata, dedica-se ao estudo da flauta e saxofone. Acompanhou cantores de festivais como Geraldo Vandré, Edú Lobo e Marilia Medalha (com Ponteio, $1^{\circ}$ Lugar no $3^{\circ}$ Festival de Música Popular Brasileira da TV Record em 1967). Mais tarde, se apresentou como compositor de Serearei, cantada por Alaíde Costa no VII FIC - Festival Internacional da Canção de 1972 e de 0 Porco da festa cantada por Aleuda e ele no Festival Abertura da Rede Globo de Televisão em 1975.

Hermeto sabia que acompanhar cantores era o ganhapão mais certo, mas sentia que não poderia se submeter para sempre às exigências dos shows, rádio e TV:

\footnotetext{
". . . sob a patrulha ideológica do nacionalista Geraldo Vandré, Hermeto trajava terno e gravata e mantinha o cabelo bem curto." (COSTA-LIMA NETO, 2008, p.24)
}

"Nem modernismo nacionalista, nem cosmopolitismo antropofágico. 0 conflito de Hermeto com a intelligentsia urbana representada por Geraldo Vandré [diversas vezes acompanhado pelo Quarteto Novo], de um lado, e com a vanguarda da música popular [termo que não se aplica aqui, segundo Hermeto Pascoal] representada por Gilberto Gil [o qual o Quarteto Novo recusou acompanhar na música Domingo no parque], de outro, marcaram o caminho pessoal que Hermeto escolheria em seguida." (COSTA-LIMA NETO, 2008, p.14)

Finalmente, o vácuo após o relativo declínio da canção brasileira com o fim dos grandes festivais abriu o espaço para a música instrumental, que levaria Hermeto a uma era de maturidade e autonomia musical:

"O predomínio do texto atingiu seu pique máximo com os festivais, nos derradeiros anos 60 e primeiros 70 - e quando a censura empenhou esforços para emudecer a música brasileira, os primeiros murmúrios da música instrumental - sem texto, portanto, teoricamente, incensurável e livre - se fizeram ouvir. . mas o jejum forçado imposto às plateias não criou de imediato um interesse por música instrumental. . . só começou a registrar dados positivos de crescimento a partir de 1974 . . . A realização, extremamente bem sucedida, de uma verdadeira maratona de música improvisada, em 78 - o Festival de Jazz de São Paulo, em setembro - serviu para atestar a existência inequívoca de um interesse pelo gênero. . . e a tendência ao modismo. 'Ouço muita gente falar do Hermeto. Mas poucos entendem', afirmou Theo de Barros, ex-companheiro de Hermeto no Quarteto Novo, em dezembro de 78. 'Não sei se felizmente ou infelizmente, ele está sendo tratado como um modismo. . '" (BAHIANA,1979-1980b, p.79-81)

"Ao se encerrar a década [de 1970], a música instrumental tinha no Brasil pelo menos dois grandes nomes. .. dois nomes que exemplificavam perfeitamente essa passagem da linha jazz/bossa para uma linguagem mais misturada e mais ampla: Egberto Gismonti e Hermeto Paschoal [sic.]" (BAHIANA,1979-1980b, p.82-83).

Em 1969, a convite da cantora Flora Purim e do percussionista Airto Moreira, que mandava notícias otimistas de sua experiência de tocar com Miles Davis, Hermeto viajou para os Estados Unidos. Lá, participou dos LPs Natural Feelings (1970) e Seeds On the Ground (1971) de Airto, atuando como compositor, arranjador e instrumentista. Através de Airto, Hermeto e Miles Davis se conheceram, após um show do jazzista norte-americano. Hermeto lembra da súbita amizade que se estabeleceu entre os dois:

\footnotetext{
"Aquele jeitão dele, meio carrancudo. . . você tem que acreditar em alguma energia celestial. Isso foi antes de começar o show. Eu acredito nisso, senti um vibração bonita dele. Ai ele fez o show dele, eu assisti o show, depois eu fui em um, dois, três shows. A música dele eu não achava boa naquela época. . . aquele rock. . . Mas ele ai me ligou e disse que queria me ver de qualquer maneira. .. Quando eu cheguei lá e tal, levei um violão, ele se sentou, toquei um monte de música[s], cantando e solando. . Quando acabei de tocar, ele chegou e disse: 'Que pena que eu não posso gravar todas as suas músicas!'. Ai eu falei: 'Mas como você sabe que eu quero te dar todas pra gravar? Eu vim também pra gravar aqui. Eu vou escolher as que eu quero te dar.' A partir daquele dia houve aquela simpatia geral. . . Ao ponto de eu ir pra casa dele e a gente lutar boxe. Uma vez eu dei uma porrada nele, errei e dei uma porrada nele. .." (BARROSO, 2009).
}

E, de fato, através de Airto, conheceu Miles Davis, que se interessou logo pelas suas músicas:

Mostrei a ele umas 12 músicas, que eram bem diferentes de tudo aquilo que ele fazia. Disse que queria colocar algumas no disco dele e eu me senti à vontade para brincar e dizer que eu veria quantas músicas deixaria ele colocar no disco dele. (IVANOV, 2002)

Ao final, fora incluidas Nem um talvez e Igrejinha no disco Live evil lançado por Miles Davis em 1972. Nesse disco histórico, além de Hermeto e Airto Moreira, participaram muitas lendas do jazz: Keith Jarret, Joe Zawinul, Herbie Hancock, Chick Corea, John McLaughlin, Steve Grossman, Dave Holland, Jack DeJohnette, Art Farmer, Wayne Shorter, Joe Farrel, Hubert Laws, Ron Carter e Thad Jones (COSTALIMA NETO, 2010a; 2000, p.124). A partir daí, só cresceu 0 reconhecimento de Hermeto em todo o mundo e a experiência de interagir com grandes artistas como Stan Getz, Joe Pass, Barney Kessel, Dizzy Gillespie, Jhonny Griffin, Opa Trio (grupo uruguaio que acompanhava Flora e Airto), Abdullah Chhadeh, Laura Fygi, Pedro Jóia, entre outros.

Hermeto tem recebido muitas homenagens e prêmios como reconhecimento pelo seu trabalho. Em 1984, foi inaugurada uma escola municipal com seu nome em Campestrinho (Alagoas). Em 1985, recebeu o título de cidadão honorário de Arapiraca, cidade vizinha à sua cidade natal. Em 1972 e 1973, recebeu os prêmios de Melhor Solista e 
Melhor Arranjador, respectivamente, pela Associação Paulista dos Críticos de Arte. No Rio, recebeu o Prêmio Sharp de Música por cinco vezes: Melhor Grupo em 1987, Melhor Disco Instrumental em 1993 com o disco Festa dos deuses, Melhor Disco Instrumental com Por Diferentes Caminhos e Melhor Música Instrumental por Pixitotinha em 1989 e Melhor Arranjo pelo disco Kids of Brazil do duo de violões Duofel. Em 1994, sua apresentação no Queen Elizabeth Hall foi considerada pelo jornal The Guardian como o maior concerto de música popular da década. Em 2002, foi homenageado pelo SESC com a exposição Hermetismos Pascoais, sobre sua obra. Ainda em 2002, os flautistas da Pró-Música do Rio de Janeiro o escolheram como tema do espetáculo 0 Aprendiz de feiticeiro. Em 2004, recebeu o Troféu Monsueto no $3^{\circ}$ Prêmio Rival Petrobrás de Música na categoria Música Instrumental pelo disco Mundo Verde Esperança, disco que ainda recebeu dois troféus no Prêmio Tim de Música. Em 2007, o DVD Chimarrão com Rapadura foi escolhido como um dos dez melhores em todo o mundo pelo historiador e produtor de jazz Arnaldo DeSouteiro, no qual Hermeto foi homenageado como Artista do Ano e Aline Morena com Artista Revelação.

Em outubro de 2002, durante um workshop em Londrina conheceu a cantora Aline Morena, descrita por um crítico argentino como "Impactante. . . con una capacidad vocal asombrosa" (MOUJÁN, 2007), e a convidou para dar uma canja no dia seguinte com o seu Grupo em Maringá. Em seguida ela o acompanhou ao Rio de Janeiro e, no fim de 2003, Hermeto, ". . . assustado com a violência no Rio de Janeiro, colocou à venda sua casa na Zona Oeste. .." (ALBIN, 2009) e passou a residir com ela em Curitiba. EnsinouIhe viola caipira, piano e percussão e, em março de 2004, estreou com ela o duo Chimarrão com Rapadura (ou seja, gaúcha com alagoano) no Sesc Vila Mariana em São Paulo (MORENA e PASCOAL, 2009a).

Hermeto Pascoal é mais conhecido tocando sanfona, fole de oito baixos, piano, flautas e saxofones. Mas, versátil multi-instrumentista e dotado de grande curiosidade em relação aos timbres, tem se expressado como virtuoso nos discos (e shows) em muitos outros instrumentos convencionais, entre eles teclados eletrônicos diversos, harmônio, cravo, órgão, escaleta, flauta de bambu, bombardino, fluguel, trumpete, violão, cavaquinho, viola caipira, bandola, craviola, clavinete, bateria, caixa, surdo, zabumba, pandeiro, pratos, triângulo - e em instrumentos exóticos, objetos e animais, como bocal de tuba, sapho, garrafas, berrante, assovio, buzinas, apitos, brinquedos, chaleira, máquina de costura, baldes, bacias, panelas, garfos, facas, balas, ruídos e gritos da voz, mangueira com voz, porta do estúdio, iefone, porcos, gansos, perus, galinhas, patos e coelhos (PASCOAL, 2009b, 2009c).

Estima-se que Hermeto Pascoal tenha composto mais de 4.000 músicas até 2007 (VILLAÇA, 2007, p.59; PRADINES, 2006), muitas das quais estão sendo editadas pelo exdiscípulo, pianista e professor Jovino Santos Neto. A sua produção fonográfica também é grande, especialmente se levarmos em consideração as dificuldades históricas que as gravadoras lhe impuseram. Seu site oficial $w w w$. hermetopascoal.com.br (PASCOAL, 2009c) lista 35 gravações comerciais, o que inclui apenas os discos em que é o artista principal ou líder de grupos, os discos em que participa como um dos solistas principais ou discos em participa como arranjador ou diretor artístico: Hermeto (1971), A Música Livre de Hermeto Pascoal (1973), Slaves Mass (1977), Missa dos Escravos (1977), Zabumbê-bumá (1979), Ao Vivo Montreaux Jazz Festival (1979), Cérebro Magnético (1980), Hermeto Pascoal \& grupo (1982), Lagoa da Canoa, Município de Arapiraca (1984), Brasil Universo (1985), Só Não Toca Quem Não Quer (1987), Por Diferentes Caminhos: Piano Acústico (1988), Mundo Verde Esperança (1989, não lançado comercialmente), Festa dos Deuses (1992), Pau Brasil e Hermeto Pascoal ao vivo, Série Música Viva (1993), Hermeto Pascoal/Renato Borghetti - CCBB, ao vivo (1993), o Melhor da Música de Hermeto Pascoal (1998), Hermeto Pascoal: eu e eles (1999), Mundo Verde Esperança (2002), Chimarrão com Rapadura (2006) em CD e DVD em duo com Alina Morena.

Hermeto aparece como arranjador, maestro e instrumentista convidado em diversos discos. Para citar panoramicamente alguns de uma enorme lista, temos: Roteiro Noturno (1964) de Mauricy Moura; The Real Bobby Mackay (1969) de Bobby Mackay, Tide (1970) de Tom Jobim, Cantiga de Longe (1970) de Edu Lobo, Natural Feelings (1970) e Seeds On the Ground (1971) de Airto Moreira, Live, Evil (Sony, 1972) de Miles Davis, Taiguara (1976) de Taiguara, Open Your Eyes, You Can Fly (1976) e Encounter (1977) de Flora Purim, Orós (1977) de Fagner, Robertinho no Passo (1978) de Robertinho do Recife, Maraponga (1978) de Ricardo Bezerra, Elis Regina, 13th Montreux Jazz Festival (1982) junto com Elis Regina, Instrumento do CCBB (1993) de Renato Borghetti (com Hermeto Pascoal), Kids of Brasil do Duofel (1996) e Stephan Kurmann Strings Play Hermeto Pascoal (2008) de Stephan Kurmann.

A estreia de Hermeto em gravações comerciais foi como sanfoneiro em três discos de Pernambuco do Pandeiro e seu Regional (CAMPOS, 2006, p.92-97, 141): No meu Brasil é assim (1954), Batucando no Morro (1954) e No arraial de Santo Antônio (1958). Gravou também no disco Ritmos Alucinantes (1956) do maestro Clóvis Pereira. Estreou como pianista em gravações no disco Boate em sua casa, vol.2 (1958) com José Neto e seu Conjunto, grupo de seu irmão mais velho. Em São Paulo, gravou flauta, recém-aprendida, no disco de estreia Caminhos (1964) do baiano pioneiro da bossa-nova Walter Santos. Ainda na década de 1960, começou a gravar música instrumental em trios e quartetos: o disco Conjunto Som 4 (1964) com o Som Quatro; o disco Em Som Maior (1965) no qual liderou o Sambrasa Trio, aparecendo também como compositor pela primeira vez com a música Coalhada; o disco Quarteto Novo (1967) com o Quarteto Novo, o qual recebeu o nome do grupo e no qual incluiu 0 Ovo, uma de suas músicas mais tocadas até hoje. Em 1969, lançou Brazilian Octopus, o disco que teve o mesmo nome do 
"grupo mais estranho surgido na música brasileira", criado para musicar os espetáculos promocionais de empresa Rhodia (Marcelo Dolabela, citado por CALADO, 2000).

No primeiro disco lançado no exterior, Hermeto (1971), os jazzistas convidados dão uma mostra do reconhecimento internacional do compositor: Gil Evans, Joe Farrell, Hubert Laws e Ron Carter, entre outros. A Música Livre de Hermeto Paschoal (1973) foi seu primeiro disco solo gravado como artista principal no Brasil e no qual consolidou seu primeiro grupo (Nenê, Mazinho, Hamleto, Bola, Alberto e Anunciação); o compacto Hermeto Pascoal (1975) foi o primeiro disco solo orquestral (com Porco na Festa de um lado e Rainha do Mar do outro). Em Slaves Mass (1977), gravado nos Estados Unidos, recorreu a dois porquinhos de estimação de dois garotinhos do Texas (veja foto do Ex.1 à p.65 nesse número de Per Musi). 0 álbum duplo Hermeto Pascoal Ao Vivo - Montreux Jazz (1979) foi seu primeiro disco ao vivo. Em Cérebro Magnético (1980), além da composição e arranjos, fez o desenho da capa.

Sete LPs - Zabumbê-bum-á (1979), Cérebro Magnético (1980), Hermeto Pascoal e Grupo (1982), Lagoa da Canoa Município de Arapiraca (1984), Brasil Universo (1985), Só Não Toca Quem Não Quer (1987) e Festa dos Deuses (1992) - são frutos do período de extrema dedicação à prática musical, no qual se consolida o trabalho de Hermeto Pascoal e Grupo. Os músicos da assim chamada Escola Jabour (ZWARG, 2009a) ensaiavam todos os dias "from 2 to 8 pm", segundo entrevista do músico Jovino a GILMAN (2009), o que é corroborado por COSTA-LIMA NETO $(2008$, p.2, 8), informando também que isto ocorreu ". . . durante doze anos consecutivos, de 1981 a 1993", sendo que esse tempo de ensaio era acrescido ". . .pela prática diária matinal, quando os músicos ensaiavam os trechos mais dificeis de suas partes individuais .... Hermeto sempre foi receptivo com músicos que quiseram conhecer sua rotina diária de ensaios. Além daqueles que se tornaram membros efetivos de longa duração no seu grupo - Itiberê Zwarg, Jovino Santos Neto, Márcio Bahia, Nenê, Carlos Malta, Antonio Luis Santana (mais conhecido como Pernambuco, mas que não deve ser confundido com Pernambuco do Pandeiro), Vinícius Dorin, André Marques, Fábio Pascoal - também passaram pela Escola Jabour os músicos Zabelê, Joyce, Jane Duboc, Aleuda, Paulo Braga, Zé Eduardo Nazário, Nivado Ornelas, Cacau, Mazinho, Anunciação, Arismar do Espírito Santo, Ricardo Silveira, Alfredo Dias Gomes, entre outros.

A fluência de Hermeto em todos os instrumentos que conheceu permite a ele realizar projetos arrojados, como gravar dois álbuns sozinho, sem outros instrumentistas: 0 disco duplo Por Diferentes Caminhos (1989), de piano solo, e o disco Hermeto Pascoal: eu e eles (1999), que se refere ao fato do compositor tocar todos os instrumentos nesta gravação. Depois da dissolução do Grupo do Jabour, Hermeto gravou alguns discos com formações menores, como Pau Brasil e Hermeto Pascoal ao vivo, com o grupo de mesmo nome (1993), Hermeto Pascoal/Renato Borghetti - CCBB, ao vivo (1993) e Solos do Brasil (2000), com o violonista Sebastião Tapajós e o pianista Gilson Peranzzetta. Em Mundo Verde Esperança (2002), depois de 12 anos, Hermeto volta a contar com a participação de Hermeto Pascoal e Grupo, e mais 13 músicos da Itiberê Orquestra Família, em um disco que 13 das 14 músicas receberam nomes dos netos de Hermeto. Nele, ainda homenageia Vitor Assis Brasil, na música Vitor, e Nivaldo Ornelas, na guarânia Camila (CALADO, 2003). Em 2003, Hermeto participou, juntamente com outros compositores como Caetano Veloso e Egberto Gismonti, de um projeto da Companhia Balé da Cidade de São Paulo para homenagear o pintor Cândido Portinari, compondo parte da trilha sonora com base no quadro Baile na roça (VILLAÇA, 2007, p.59).

Chimarrão com Rapadura (2006) reflete a mais recente parceria de Hermeto Pascoal: Aline Morena, uma multiinstrumentista que, além de se tornar sua esposa, abraçou sua concepção de música universal. Nas 19 faixas deste disco, cujo título explicita uma integração entre o Nordeste e o Sul do Brasil (gaúcha com alagoano), o duo utiliza dezenas de instrumentos, convencionais e exóticos, como a porta do estúdio onde gravaram, balde, garfo, faca, chaleira, mangueira com voz, vestido de copos de iogurte, chapéu de castanholas, bota, sapatilha, plástico no tablado, saia de alumínio, percussão com água e boca, entre outros.

Atualmente, Hermeto mantém uma agenda cheia de compromissos no Brasil e no exterior, apresentando-se com cinco formações diferentes: solo, com seu grupo, em duo com Aline Morena e à frente de big bands e orquestras sinfônicas.

\section{3 - 0 afeto, a alegria e apoio familiar contra as dificuldades do mundo}

"Como será a cidade grande? 0 mar. . . Como será o som do mar?" Hermeto Pascoal, aos 14 nos, antes de sair de casa (VILLAÇA, 2007, p.31)

A trajetória vitoriosa de Hermeto Pascoal contrapõe-se aos muitos nãos e hostilidades que recebeu ao longo da vida. Isto se deve, em grande parte, ao apoio que sempre recebeu dos pais, Seu Pascoal e Dona Divina. 0 triunfo do autodidatismo que o acompanhou até a maturidade sobre 0 academicismo tem raizes na sólida e afetiva estrutura familiar:

\footnotetext{
"Hermeto sempre soube que era diferente, mas nunca se sentiu inferior nem desenvolveu complexos - aliás, eis um caso em que se pode afirmar: muito pelo contrário. Ainda era menino, em Lagoa da Canoa, a molecada da escola colocava um apelido atrás do outro, era aquela zuada - e ele nem aí. Era tão talentoso e divertido que no fim as meninas mais interessantes gostavam dele. E bastava um chamego para a turma cair em cima: 'Como é que você namora um cara desses, ele não enxerga direito e o olho dele vira!' Na saída, Hermeto ia em um por um - era mais fortinho. 'Você falou que eu sou feinho?' E pá neles. Mais tarde, sempre aparecia um pai ultrajado. 'Seu filho bateu no meu.' Seu Pascoal, tranquilo, olhava pra Hermeto. 'Filho, por que você bateu?' Primeiro ouvia, depois acrescentava: 'Então fez certo'. A mãe, dona Divina, dava também aquela proteção. Acontecia, por exemplo, de as mocinhas lavando roupa no rio começarem a fazer troça com o menino. 'Que esquisito, olha como ele é branco! Você enxerga bem?' Hermeto tinha pronta a resposta: 'Levanta a
} 
saia que eu digo'. E lá iam as mocinhas fazer queixa do galego com dona Divina. Que primeiro ouvia, depois... 'Respondeu certo. E tem mais: fui eu que ensinei.' É por isso, graças a seu Pascoal e a dona Divina, que Hermeto se gosta, se acha bonito. 'Sou uma árvore muito original'." (0. RODRIGUES, 2003).

0 seguinte diálogo, recuperado da infância de Hermeto, mostra seu avô tranquilizando sua mãe sobre seu talento musical:

"Pai, eu acho que Sinhô ta doido! Meu filho tá doido! Sabe aqueles ferros que o senhor joga fora? 0 Sinhô pegou uma porção deles!. . . Deixe o menino brincar. . E ele tá lá até agora, trancado, batendo nos ferros. . . Olhe minha filha, eu acho que quem está doida é você! Ele está tocando. . .o baião Asa Branca de Luiz Gonzaga, que tanto tocava na feira..." (VILLAÇA, 2007, p.22)

Numa carta de 30 de abril de 2003 a seu ex-aluno do curso primário, Zélia Gaia se lembra ". . . dos pandeirinhos de latas de goiabada que Dona Divina, sua mãe, ensinava a fazer. . . das flautas de carrapateira que fazíamos na escola. .. ricas experiências. .." (GAIA, 2003). A paciência que Hermeto encontrou na sua primeira e amorosa professora, não encontrou depois nos professores de música que procurou: "Há muitos anos, arranjaram um professor para me ensinar teoria, mas ele se recusou porque eu não enxergava direito." (GONTIJO, 2000, p.2). Para CABRAL (2000, p.11),

\begin{abstract}
"Hermeto Pascoal é um desses brasileiros que, pela determinação e pelo talento, conseguiram superar as deficiências do nosso sistema educacional. Nascido e criado em uma região desprovida de escola de música, ainda assim sempre quis ser músico ... assumindo sozinho, a própria educação. . . teve só uma professora na vida: dona Zélia, que o alfabetizou. ..."
\end{abstract}

Em Recife, Hermeto encontrou muitos obstáculos. Do produtor musical da Rádio Jornal do Commercio e patrão Amarílio Niceias, ouviu: "Você não toca bem a sanfona. . . Nem oito nem oitenta [baixos]!. . . Se quiser continuar na rádio, vai ter que tocar pandeiro. . . Você não tem é jeito pra música!" (VILLAÇA, 2007, p.39). Mas isto não foi empecilho para o determinado músico: Sempre prevaleceu seu otimismo: "Siga em frente! Você tem o dom da música! Confie em você!", dizia para si mesmo (VILLAÇA, 2007, p.40).

Certo dia, em Caruaru, já conhecido como bom sanfoneiro, Hermeto achou uns penicos de ágata em um ferro-velho e os levou para tocar em um estúdio da rádio. VILLAÇA (2007, p.44-45) reconstrói o diálogo entre ele e os colegas músicos galhofeiros:

\footnotetext{
"- Que loucura é essa? 0 que é isso?

- Isso é música, ouça que maravilha! A ágata dá um som danado!

- Não, isso é só um penico - zombou um deles.
}

Hermeto ficou sério: - Os objetos têm sons. Estão só esperando para serem usados como instrumentos.

\footnotetext{
. . .0 máximo que Hermeto conseguiu foi arrancar o riso de seus companheiros."
}

$\mathrm{Na}$ volta ao Recife, já saudado por Sivuca como o "0 Maior Sanfoneiro do Agreste" (BARROSO, 2009), Hermeto não guardou ressentimentos contra o produtor da Rádio Jornal do Commercio Amarílio Niceias: "Eu não fiquei revoltado com nada disso. .." (CAVALCANTI, 2004), pois queria apenas ". . . mostrar pra esse cara, sem raiva dele, que ele me fez um bem, não me fez um mal. Ele se arriscou, ele podia ter feito um mal se eu fosse um cara que não tivesse a força que eu tenho. Eu poderia ter me dado mal, ter ficado desgostoso. Escutar um negócio desses com 14 anos de idade. .." (BARROSO, 2009).

Já reconhecido como excelente instrumentista no meio musical em São Paulo, Hermeto ainda era visto cinicamente por boa parte da crítica especializada como "hermético" (CABRAL, 2000, p.12). Não faltaram produtores que quiseram manipular seu talento em prol da indústria fonográfica. Hermeto fala do episódio em que foi convidado para gravar um disco como artista principal na Continental:

"O primeiro contrato que eu fui assinar era na Continental, com um produtor de disco e os produtores eram 'donos dos músicos'. Quando eu fui convidado pra gravar, pra mim era uma grande chance, uma oportunidade de gravar, as minhas músicas todas debaixo do dedo para tocar. Quando eu chego lá, tava lá uma lista, um papel com um monte de nomes de músicas. Aí ele pediu para eu sentar, e começou a ler, e disse: "E agora? Está bom essas músicas aqui?" Eu digo: "Pra que?". [Produtor:] "Já escolhi as músicas pra você gravar". [Hermeto:]"As minhas músicas, o senhor me desculpe, mas, modéstia parte, quem escolhe sou eu. Isso ai que o senhor me falou, não são músicas, são letras. Tá muito ruim, quadrado. Isso aí eu toco na noite algumas vezes, uma ou duas dessas". . . E eu estava na faixa dos 20 e poucos anos. [Produtor:] "Mas menino! Você vai perder uma chance dessas de gravar na Continental?" Eu digo: "Porque eu vou gravar? Porque eu sou bom músico ou não?". [Produtor:] "É, mas você tem que escolher música conhecida". Eu disse: "Mas eu quero ficar conhecido, se eu tocar música conhecida eu não vou ficar conhecido. Eu quero que as minhas músicas também fiquem conhecidas e que eu fique conhecido através das minhas músicas. Se for assim eu gravo, se não for assim, eu quero lhe agradecer, desculpa, mas eu não quero gravar nunca, não é só hoje não. Não quero que ninguém me convide, pode avisar para todos seus amigos empresários, diretores, que eu não quero gravar nunca a não ser as minhas músicas e como eu quero tocar. Não abro mão do jeito que eu quero gravar. Quem me chamar para gravar com alguém, tem que ser como eu quero tocar. Não estou precisando de nada, não quero nada" (BARROSO, 2009).

Falando sobre a música comercial-popular brasileira, WISNIK (1979-1980, p.7) distingue

\footnotetext{
". . . dois modos de produção diferentes, tensos mas interpenetrantes dentro dela: o industrial, que se agigantou nos chamados anos 70, com o crescimento das gravadoras e das empresas que controlam os canais de rádio e TV, e o artesanal, que compreende os poetas-músicos criadores de uma obra marcadamente individualizada, onde a subjetividade se expressa lírica, satírica, épica e parodicamente."
}

Dentro desta música artesanal, Hermeto criou, ainda, um nicho ainda menos comercial, menos disposto, como se tornou chavão na gíria cultural brasileira, "a fazer concessões". A opção de Hermeto por uma música instrumental mais sofisticada, mesmo em discos de cantores, é quase religiosa e deixou uma produção histórica, como foi mostrado acima. Ele não abre mão de sua posição radicalmente oposta à linha comercial geralmente imposta pelas gravadoras e mídia: "Essa turma não evoluiu nada. Minha intenção ao trabalhar com eles foi abrir a cabeça deles, 
mas eles apelaram: foram fazer música para novela. Como o meu amigo Fagner, que criticava a TV Globo e acabou cedendo. Ganhou muito dinheiro, mas cadê a alegria interior?" (CALADO, 2003). Perguntado sobre seus cantores preferidos, Hermeto parece se identificar apenas com aqueles dispostos a uma interação mais flexível e menos óbvia com a parte instrumental, aqueles que valorizam a criação, a improvisação. Cita alguns, como Johnny Alf e Guinga, mas diz que não ouve "figurões" como Chico Buarque, Caetano Veloso e Gilberto Gil, apesar de gostar deles, pois ". . . isso já passa no rádio, né? Aliás isso tem a ver com aquilo que falei sobre o não evoluir. .." (IVANOV, 2002). Entre as cantoras, elogia a "genial Jane Duboc, quebramos tudo que tinha direito" (PASCOAL, 2000a, p.101-102) e dedicou a balada Dá-Ihe coração a Eliane Elias, a quem diz ". . . ter visto nascer musicalmente" (MILLARCH, 1989c).

Mesmo no meio puramente instrumental, Hermeto mostra-se muito exigente. Ele não tem boas lembranças do encontro que seria o sonho dos fãs da música instrumental brasileira, o show Virada do milênio realizado no ATL Hall no Rio de Janeiro em 1999, quando tocou simultaneamente no palco com três outros grandes pianistas brasileiros - Arthur Moreira Lima, Egberto Gismonti e Wagner Tiso:

\section{".. . 'Foi aquela coisa que se imagina que vai ser muito bom e acaba não sendo. Era para ser algo de improviso e o Egberto e o Wagner se prepararam para isso. Foi uma briga, não foi música. 0 Arthur, que era o erudito, foi o que mais me surpreendeu e se soltou. Carregamos os outros nas costas', diz, brincando à sério. Arthur [presente à entrevista], depois, confirmou a coisa toda com um riso." (IVANOV, 2002)}

A imagem messiânica de Hermeto Pascoal que seus admiradores adotam parece derivar da religiosa obsessão com que vive a música no seu dia-a-dia. Esta devoção, que às vezes parece beirar o transe religioso, é aparente também nos shows, como em uma inauguração de uma casa de jazz em Pendotiba (Niterói), na qual Hermeto e seu grupo ". . . tocaram por cinco horas e meia" (COSTA-LIMA NETO, 2008, p.9). Em outra oportunidade, durante o $1^{\circ}$ Festival Internacional de Jazz, realizado em São Paulo em 1978, o show de Hermeto ". . . começou às 23 horas e prolongouse até às 4 horas da madrugada, e com nomes internacionais como McLaughlin, Chick Corrêa e Stan Getz subindo ao palco e, praticamente pedindo para se integrarem ao seu som totalmente inusitado, múltiplo. .." (MILLARCH, 1979). Esta obstinação em que cria um mundo particular com a música e que não se enquadra dentro dos limites de horário dos teatros onde se apresenta tem rendido a Hermeto algumas dificuldades. Na sua segunda apresentação durante os concertos do festival Som da gente no Town Hall em Nova lorque em 1989, sentiu-se tolhido ao saber do tempo que teria e

\footnotetext{
". . .não fez por menos: após demorar-se em falar numa homenagem a alguns amigos presentes - como a pianista Eliana Elias e o baterista Dom Um Romão (que subiu ao palco, para um demorado abraço) ou ausentes - Miles Davis, que Ihe havia telefonado à tarde - referiu-se a uma suite de 20 minutos que ainda está compondo, 'mas que gostaria de apresentar'. . . começaram a mostrar a belissima composição, mas não passaram dos primeiros acordes;
}

Hermeto interrompeu a apresentação, dizendo que o seu tempo de show havia acabado. . Todos retiraram-se para os bastidores enquanto o público que lotava o Town Hall, em pé, aplaudia e gritava o seu nome, pedindo o retorno do grupo... Apesar do estímulo de Rob Crocker, um dos mais populares apresentadores da WOCD-101. . . Hermeto e seus músicos não retornaram ao palco. As lâmpadas foram acesas e o público deixou o teatro entusiasmado com a música que ouviu naquela noite mas, no fundo sentindo que Hermeto não tivesse mostrado mais de seu som original, rico e harmonioso." (MILLARCH, 1989b)

Em outra oportunidade, apresentando-se no Rio Monterey Jazz Festival em 1980 no Rio de Janeiro, não teve paciência com o público e sua interferência:

\begin{abstract}
". . . Hermeto falou muito, experimentou vários instrumentos e fez alguns trocadilhos. Depois reclamou do barulho. Deu um aviso prévio. Começou a fazer um belissimo solo de flauta, com o tema que apresentou em Montreux (gravado no LP da WEA, nas lojas), mas parou ao ouvir o barulho entre o público que se acotovelava a sua frente. E, irritado, saiu do palco, sob vaias. Tumultos, confusão. Voltou minutos depois, mas recebido com vaias, jogou a flauta no chão e se foi. Mais tarde, nos bastidores, disse que gostaria de 'tocar para a imprensa'. A noite mais longa do festival acabou mais cedo." (MILLARCH, 1980a)
\end{abstract}

Depois das primeiras experiências de gravação com grupos de regionais, Hermeto trabalhou com grandes gravadoras multinacionais, como EMI (1967), Polygram (1973 e 1992) e WEA (de 1977 a 1980), mas as dificuldades crônicas com a política comercial das mesmas o direcionou a pequenas gravadoras, como Som da Gente (1981-1993) e Maritaca:

"Convites eu sempre tive, mas não quero mais gravar por gravadoras grandes. .. Elas não evoluíram nada. Querem gravar comigo só para dizer que têm Hermeto Pascoal no catálogo. Me tratam como aquela jóia exposta na vitrine para deixar as pessoas com água na boca, mas que ninguém consegue comprar." (CALADO, 2003)

A saída encontrada por Hermeto para o tratamento hostil e explorador que as gravadoras lhe destinam é extrema e tem resultado na liberação ou perda de seus direitos autorais. Em relação às cópias domésticas do LP Brazilian Octopus no formato CD que estavam circulando em São Paulo, foi categórico: "Se a gravadora não se interessa em fazer o $C D$, essas pessoas têm que copiar mesmo. É o único jeito que o público tem de ouvir a nossa música" (CALADO, 2000). MILLARCH (1979) relata que ". . .o próprio Hermeto recomenda que todos que vão assistir seus espetáculos devem levar gravadores, pois nunca há a mesma sequência, o mesmo show.". Ele, às vezes, deixa transparecer sua revolta com os impedimentos de socializar sua obra com o público:

Meu discos estão sendo pirateados pelas Gravadoras. As minhas Gravadoras lançam os meus discos e não me dão satisfação. . . Nenhuma delas tem um recibo assinado por mim lá, deles pedindo uma autorização para lançar meus discos. Eu sei que as músicas são deles, mas para todos discos eu tenho direito autoral. . . Eu já falei: PIRATEIEM MEUS DISCOS. . Não toco em rádio, pirateiem, vendam. Quem está dizendo sou eu. . . A [Rádio] MEC é uma rádio pobre. .. é do governo. .. Nós queremos a cultura. Mas se eles não tocarem. . . eu dou essa porra também. Eu quero é isso. Pirateiem os discos do Hermeto, estou mandando piratear, eu assumo. . Todas são Ladras, estão me roubando e vão me roubar até eu morrer. . . Eu nunca recebi mil reais no Brasil, já assinei 70 recibos no ECAD de Brasilia e nunca foi [equivalente a] mil reais. Da editora na França eu recebi seis mil reais da primeira vez. Aqui, a Rádio 
MEC fez cinco mil discos, mas não tem distribuição. . . Eles falam, anunciam na rádio dizendo: "Nas boas lojas". Que boa nada, tem que vender em qualquer lugar. .." (BARROSO, 2009).

Mas a vingança de Hermeto "tocando viola de papo pro ar" contra a indústria fonográfica já começou. 0 advento da internet ofereceu a Hermeto um instrumento ideal para socializar sua música. Ao comentar sobre o projeto de disponibilização gradual e gratuita da obra de Hermeto Pascoal no site www.hermetopascoal.com.br a partir em meados de 2007, Aline Morena comenta sobre a política injusta das multinacionais da gravação: "Então, adeus às grandes editoras que fizeram isso até hoje. Que elas aproveitem enquanto podem, porque vamos oferecer tudo gratuitamente." (CASTRO, SOUZA e ROCHA, 2007). Em 2008, Hermeto decidiu declarar livre acesso para aqueles que quiserem gravar sua obra. Em uma folha colorida a lápis e emoldurada com desenhos de fermatas, acidentes musicais e um auto-retrato, o compositor documenta sua postura universalizadora: "Eu, Hermeto Pascoal, declaro que a partir desta data libero, para os músicos do Brasil, e do mundo, a gravação em CD de todas as minhas músicas que constam na discografia deste site [www.hermetopascoal.com.br]. Aproveitem bastante. Hermeto Pascoal. Curitiba 17 do 11 de 2008. Testemunha: Aline Morena" (PASCOAL, 2008).

Jovino, que guarda boa parte dos originais da obra de Hermeto, fala sobre o que considera sua missão após a dissolução do Grupo:

\begin{abstract}
"Desde que sai do Hermeto Pascoal e Grupo em 1993, disponibilizar sua música para músicos em todo o mundo se tornou uma de minhas prioridades. Sempre fui uma espécie de bibliotecário dos manuscritos, organizando-os e guardando-os. Quando me mudei para Seattle, comecei a editar algumas peças em computador. Agora estamos perto de publicar um livro com parte de sua música para piano solo. Em seguida, viriam música para grupos de flautas, quartetos de cordas, peças sinfônicas, para big band e, claro, alguns dos arranjos para nosso Grupo. Tenho cerca de 1.000 peças em arquivo, o que será muito trabalho. Entretanto, sou 0 responsável por isto e considero minha missão garantir que este acervo musical surpreendente seja conhecido e ouvido. Trabalho diretamente com o Hermeto neste projeto e esperamos ter o primeiro livro em breve" (GILMAN, 2009).
\end{abstract}

Com os colegas, Hermeto também aprendeu a lidar com constrangimentos profissionais de uma maneira positiva, como no polêmico episódio com Miles Davis. Numa época em que os produtores do grande trompetista de jazz não se preocupavam em dar os créditos de músicas de outros compositores, Hermeto não teve seu nome incluido como autor das músicas Nem um talvez e Igrejinha gravadas no disco Live evil, lançado em 1972.

MILLARCH (1988), citando outra escorregadela de Miles Davis, em que ele aparece como autor de Corcovado (Tom Jobim) e Aos pés da Santa Cruz (Marino Pinto e Zé da Zilda) no disco Quiet Nights (1962), o chama de "... useiro em se apropriar de temas alheios, tendo feito isto com 'Igrejinha' de Hermeto Paschoal, só pagando direitos após ameaças judiciais e mil broncas de Airto." 0 erro não deixou Hermeto magoado: "Houve uma confu- são e, mais tarde, tudo foi resolvido" (COMODO, 1996), explicando que "Eu gravei no disco do Miles Davis duas músicas minhas e saiu que o Miles tinha roubado as minhas músicas. Saiu mesmo o nome dele nas minhas músicas. Mas jamais eu, pelo conhecimento que eu tenho com ele, [digo que] jamais ele ia fazer isso comigo, nem com ninguém" (BARROSO, 2009).

A determinação e a alegria parecem, de fato, nortear a vida de Hermeto Pascoal. Com o humor cáustico que permeia os relatos de sua expedição para conhecer de perto a música brasileira, o jornalista norte-americano John KRICH (1993, p.117-118) comenta que Hermeto poderia ter razões para ser infeliz: ". . . obeso, um olho-virado, atributos realçados pela barba de Papai-Noel despenteada e a massa de cabelos brancos anelados que repousa sobre sua cabeça como tirinhas de papel de empacotar". Mas se redime dizendo que

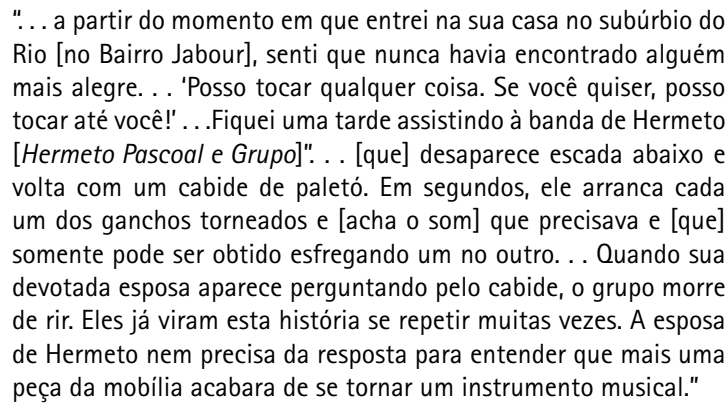

0. RODRIGUES (2003) relata outro trecho que sugere a rejeição da mídia ao aspecto visual de Hermeto, que tem, no humor, um aliado para brincar com situações difíceis:

"Pouca gente lembra, mas em 1967, no III Festival de Música Popular Brasileira da Record, foi o Quarteto Novo - Hermeto, Heraldo, Théo de Barros e Airto Moreira - que ajudou "Ponteio", de Edu Lobo, a chegar ao primeiro lugar. De vez em quando, trechos do festival são reprisados e quase nunca se vê Hermeto no palco, só suas mãos tiritando na flauta. "Eles deviam me achar muito feio pra mostrar." Numa dessas grandes noites, ele se escondeu atrás de um cenário. Logo, o diretor apareceu para ver o que estava acontecendo. Hermeto: "Meus filhos estão duvidando que eu toco na televisão". Nunca mais sumiram com ele."

Este mesmo humor com que tem driblado os obstáculos que encontra pela vida, aparece na sua música. Entre seus projetos estava a ideia de transformar em música uma fita que recebeu de um gago alemão recitando poemas de amor (COMODO, 1996). Juntos, o humor e a alegria fazem parte da memória afetiva de Hermeto, nos festejos populares nas ruas do Brasil, como na reencarnação das bandinhas, que Jovino presenciou como membro do Grupo:

"Certa vez, em 1982, durante o concerto no Teatro IBAM, começamos a sair do palco com o piccolo, dois saxofones, tuba e percussão e depois, para fora do teatro, nas ruas, tocando alguns temas que o Hermeto havia escrito para aquela formação. A plateia nos seguiu. Desfilamos por um tempo e, então, voltamos para o teatro pra terminar o show. Aquilo criou situações extremamente engraçadas, como subir nos ônibus coletivos, entrar nos bares e, algumas vezes circular centenas de metros longe do teatro; Algumas vezes, tínhamos milhares de pessoas dançando atrás da gente nas ruas." (GILMAN, 2009) 
Esta mesma memória afetiva que lhe remete sempre às suas raízes, à sua família, o motiva musicalmente. $A$ voz do pai, Seu Pascoal, incluiu na faixa São Jorge, no disco disco Zabumbê-bum-á (1979). Na gravação de Santo Antônio, no mesmo disco, Hermeto gravou sua mãe Dona Divina descrevendo um ritual típico do interior, improvisando pedidos de prenda em uma típica procissão nordestina do santo casamenteiro. Hermeto achou, nas dificuldades encontradas pela vida, motivações para traçar seu caminho e viver bem. Não é à toa que a frase escolhida por ele para finalizar cada uma das 366 partituras do Calendário do som foi o voto generoso e otimista "tudo de bom, sempre".

\section{4 - A natureza}

"Os animais são meus maiores professores." Hermeto Pascoal (0. RODRIGUES, 2003)

A bandeira ecológico-musical de Hermeto pode ser apreciada nos títulos de suas músicas, como Dança da selva na cidade grande, Terra verde, Música das nuvens e do chão, Peixinho, Nascente, Quando as aves se encontram nasce o som, Caminho do sol, Fauna universal, Água limpa, Saudade do Tietê, Batucando nas Matas, Cordilheira do Andes, entre outras. E também em vídeos. Por exemplo, Hermeto Pascoal e Grupo foram temas do vídeo ecológico Bagre Cego de Ricardo Lua (disponível em www. youtube.com como Hermeto e Grupo, Ballad for a blind albino catfish), em que ele e seus músicos aparecem fazendo música nas cavernas do Vale do Ribeira, em São Paulo, ameaçadas de destruição (MILLARCH, 1986). Já no vídeo Hermeto Pascoal and the music fom the frogs (disponivel em www.youtube.com), Hermeto fala sobre a natureza e, tocando uma flauta de bambu ininterruptamente, entra em um poço de um riacho e gradualmente, saltando como um sapo, desaparece sob as águas. Este envolvimento com a natureza é antigo. Ele relata:

\footnotetext{
"Eu comecei a tocar no mato tudo que tinha de coisa . . Então a gente inventava. Eu inventava muito. . . Você começa a analisar suas coisas de criança. Foi quando eu comecei a ver esse lado todo, o lado dos animais, que eu conversava com os animais, naturalmente. Eles entendiam tudo, a gente se entendia. Eles me entendiam porque eu via a ação deles. . . o cavalo fazia com a orelha. Eu sabia os sinais. Por exemplo: Quando o cavalo via uma visage. 0 quê que é uma visage? É uma visão, uma coisa espiritual, uma energia. Que o animal é muito sensível. A gente põe eles no lugar errado, acha que o animal não tem espírito. É conversa fiada. 0 espirito deles é tão elevado quanto o nosso. .. Os sapos são gênios! São gênios, escondidos, excluidos por nós. Os sapos já dão a aula do que é orquestração natural. Eles são gênios, os sapos, os pássaros. Deus botou os animais como o espelho verdadeiro da vida. .. 0 porco é tido como rude, talvez o animal mais rude que tem. . . Ele queria justamente [ouvir] um instrumento médio. Eu pegava um talo de abóbora. . . rachar no meinho com uma faquinha, com cuidado. . . e sopra como se fosse aquelas gaitas escocesas, empurra no céu da boca, que fica aquele som assim, de céu da boca, como gaita escocesa. . . 0 porco, você toca aquilo ali, ele pára. . Você sentia a felicidade dele. . Hoje em dia, eu posso fazer com sax soprano. .. o porco vai delirar com você..." (BARROSO, 2009).
}

Os sons da natureza foram os primeiros sons musicais a habitarem a mente de Hermeto Pascoal; eram sons de altura "indeterminada" (cuja fundamental não é claramente distinta ao ouvido humano), antes mesmo dos tons e semitons do pé-de-bode de seu pai. Muito antes do conceito de paisagem sonora de Murray Shaffer: "Até os 14 anos fiquei lá em Lagoa da Canoa em contato total com a natureza, com todos os animais. . não escutava nem rádio porque nem havia luz elétrica. .." (CAVALCANTI, 2004). Já adulto, Hermeto resgatou imagens da infância, de sua comunhão com a natureza e as reverte em música, como em Mercosom do álbum Hermeto Pascoal: eu e eles, 1999):

Um dia, na estrada até Lagoa da Canoa, ele descobriu as formigas em travessia, trabalhando duro. Tiveram de chamar seu Pascoal em casa: 'Seu filho ficou maluco, está deitado lá na estrada e não quer deixar os vaqueiros passarem com a boiada.' Uma das coisas que encanta Hermeto é o que ele chama de 'sonzinho' das formigas. 'Aquela areia branca, elas se arrastando na areia. . . Na gravação de um disco, comecei a me lembrar desse sonzinho, fiz assim na calça, saiu algo interessante. 0 técnico se assustou. Ai pronto, já comecei a tocar um forró. Você escuta um som que parece zabumba, mas não é: é calça jeans! Você vê que tudo é música. $E$ isso que eu tô falando vale pra vaca, cavalo, boi, vale pra todos eles.' 0 . RODRIGUES (2003)

Em entrevista sobre o primeiro disco Mundo Verde Esperança (1989; não lançado comercialmente; o segundo Mundo Verde Esperança foi lançado em 2002), Hermeto Pascoal relaciona seu pensamento ecológico-musical com uma filosofia de vida que aprendeu no interior do Brasil:

\begin{abstract}
"Eu, que sou um cara da roça, que fui criado na roça, via muito bem que o dono do cercado tinha o cuidado de fazer uma vala do tamanho do terreno e plantava um negócio chamado macambira, que não pega fogo, para que o dono do outro terreno pudesse preparar o terreno para plantar, sem prejudicar o vizinho. Tudo era bem feito, feito com muito cuidado. Creio que isso acontece na música também." (CASTRO, SOUZA e ROCHA, 2007).

"... passarinhos, formigas, sapos, porcos, bois, cavalos. 'Os animais são meus maiores professores.' E é na terra natal que Hermeto recebe as primeiras bênçãos do sol, da chuva, do mato, do vento; é onde ele descobre o som da areia e percebe as vozes da alma. 'Eu arrancava um pedaço de carrapateira, aquele canudinho da mamona, e com uma faquinha fazia uma flautinha e começava a tocar. Primeiro, aquele som novo assustou os bichos. Mas aos poucos. .. Eu começava a tocar uma melodiazinha e ficava naquela só, para eles se acostumarem. No segundo dia já tinha dois. No terceiro, foi aumentando, aumentando, a ponto de eu tocar tudo que quisesse. Agora não precisava mais escolher a musiquinha pra eles, não. .. Quando eu tocava o primeiro som na flauta, eles vinham e cobriam a árvore.' 0. RODRIGUES (2003)
\end{abstract}

Esta aprendizagem inicial, não orientada pela tradição europeia, acompanhou Hermeto no seu contato com as outras músicas: "Quando eu era pequenininho tocando a oito-baixos, com 8, 9 anos de idade eu tava tocando forró. .. baile, casamento e quando eu pegava na oito-baixos, eu já 'entortava' a oito-baixos. .. umas músicas muito doidas. Eu extraía dos ferros, das pancadas que eu dava nos ferros, aquelas harmonias" (COSTA-LIMA NETO, 1999, p.78). Para Hermeto, "0 atonal é a coisa mais natural que existe", o que levou COSTA-LIMA NETO (1999, p.190) a propor a perspectiva de uma trindade sonora experimental cujas raízes estão na infância do músico alagoano, e que, mais tarde, passou a subsidiar o sistema musical singular de Hermeto, incluindo suas melodias e harmonias. Esta trindade sonora paradigmática, segundo a qual som musical e ruído são equivalentes, é derivada de três fontes 
distintas, percebidas por Hermeto graças a sua escuta ampliada: sons de animais, sons dos objetos e sons da voz humana. 0 próprio Hermeto percebe uma relação do atonalismo que chama de "fala dos objetos" com o atonalismo que ouve na fala humana, que conceituou com música da aura: "Os pedaços de ferro já tinham alguma coisa a ver com a música da aura. . . o som da aura que percebi desde minha infância. .." (COSTA-LIMA NETO, 2000, p.131-132). Assim, se nos objetos, que são instrumentos musicais esperando para serem tocados - como os "resultados incríveis" das moedas de 25 centavos de dólar (além do pé esquerdo de seu sapato!) que colocou entre as teclas de um Steinway para provocar o público novaiorquino (MILLARCH, 1989b) -, ele percebe a música dos ferros, nas pessoas ele percebe a música da aura.

Na sua análise da música Ferragens para piano solo, COSTA-LIMA NETO (2000, p.135) observa a intenção programática nas indicações de pedal e de fermatas sucessivas, como uma representação da reverberação que descreve os sons de pedaços de sucata de ferro do avô ferreiro Sena da Bolacha que povoaram sua prática musical na infância. Do ponto de vista harmônico, as alturas "indeterminadas" traduzidas para o piano resultam em clusters acompanhando uma melodia atonal e fragmentada (Ex.1). Entretanto, estas ". . . combinações harmônicas complexas. . ." têm raízes em ". . . elementos harmônicos simples como as tríades. .." (COSTA-LIMA NETO, 1999, p.94-96).

0 conceito de música da aura surgiu na década de 1980, quando se deu conta de que "0 cantar das pessoas, na minha concepção. . . é o que chamamos de fala. Assim como os pássaros, nós somos pássaros também" (entrevista a Luis Carlos Saroldi da Rádio MEC em 1997, citado por COSTA-LIMA NETO, 1999, p.177). No disco Lagoa da Canoa, município de Arapiraca (1983), na faixa Som da aura, ele utilizou os famosos trechos onomatopaicos de narração esportiva "tiruliruli-tirulirulá" e "parou, parou, parou" dos locutores esportivos Osmar Santos e José Carlos Araújo, respectivamente. Hermeto descreve o procedimento para a realização da música da aura, simples para ele que tem ouvido absoluto e uma prática de reconhecimento auditivo enorme: "É muito fácil tocar o som da aura, que nada mais é do que a energia do som de cada pessoa através da música. E quando eu escuto a voz da pessoa, eu toco aquilo que estou escutando" (ESSINGER, 2000).

No disco Festa dos deuses (1992), pode-se apreciar várias instâncias de música da aura. Uma análise auditiva de três destas músicas - Pensamento positivo (a partir de uma fala do Presidente Collor de Melo), Aula de natação (a partir de uma aula ministrada pela filha Fabíula Pascoal) e Três coisas (a partir de um poema de Mário Lago recitado por ele mesmo) - mostra procedimentos comuns: (1) escolha de trechos da fala humana pré-gravadas como ponto de partida para a criação musical, (2) apresentação da fala sozinha primeiro, (3) repetição da fala com dobramento instrumental de teclados (piano e harmônio) aproximando de suas alturas "indeterminadas" e ritmos, o que resulta em um contorno melódico atonal heterofônico (um "quase-uníssono"), (4) acompanhamento com acordes esparsos em encadeamentos não funcionais ou atonais. Jovino, que foi quem tocou piano e harmônio nestas três faixas, observa que

\footnotetext{
"A música da aura ainda está nos seus estágios iniciais. . . pode imaginar um filme em que os diálogos do atores é também a trilha sonora? . . Embora outros tentaram algo similar, em minha opinião, somente Hermeto conseguiu capturar a essência musical da fala." (GILMAN, 2009)
}

Na faixa Três coisas, Hermeto Pascoal, Jovino Neto e Fábio Pascoal avançaram um pouco além desta fórmula básica acima, descobrindo redundâncias de células rítmicas na declamação poética de Mário Lago e as acompanhando com levada e instrumentação de baião; coincidindo cadências da fala com triades perfeitas maiores e menores. Ainda no disco Festa dos deuses, a faixa Quando as aves se encontram, nasce o som também pode ser considerada música da aura, mas os elementos primários aqui são as "vozes" de aves (uirapuru, sabiá, corvo, fogo-apagou, galo, bacurau, marreco) com um tratamento mais sofisticado: há solos a cappella alternando com trechos acompanhados (com Hermeto nos teclados), dobramentos que se entrelaçam, células manipuladas com loops, acompanhadas com levadas de gêneros diversos (samba e valsa), harmonias contrastantes (atonalismo, tonalismo, modalismo, cromatismo). Embora a transcrição musical de can-

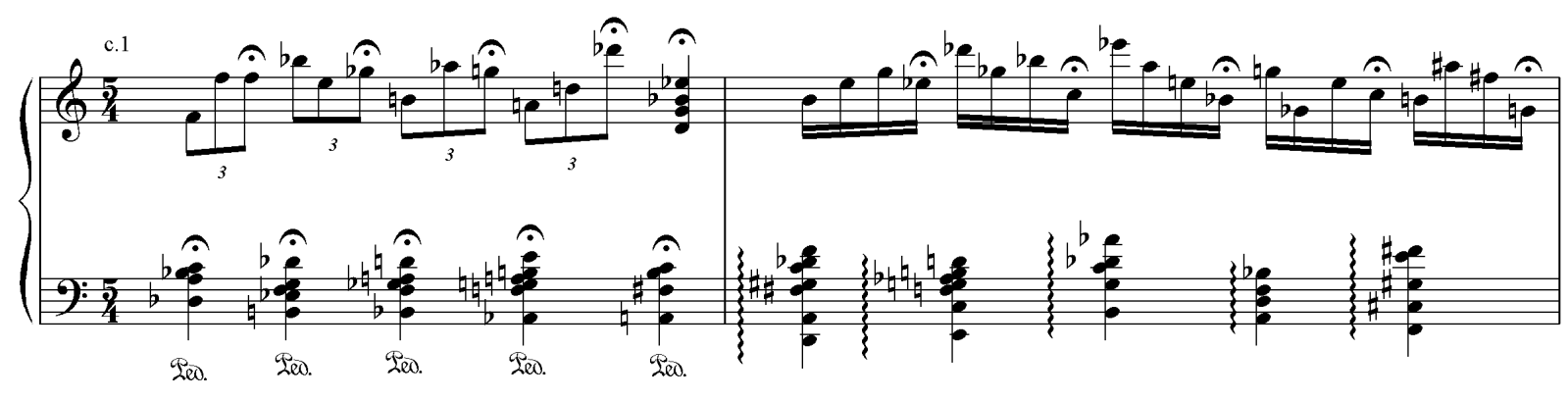

Ex.1 - Exemplo de música dos ferros com clusters atonais em Ferragens de Hermeto Pascoal. 
tos de pássaros nos remeta à iniciativa do compositor e ornitologista Olivier Messiaen, a abordagem de Hermeto é única no sentido da eclética liberdade de compor com os motivos que descobre nos cantos e as associações que faz com a rítmica popular.

Muitos dos animais que povoaram a infância de Hermeto reaparecem na sua obra. No disco Slaves Mass (1977), por exemplo, Hermeto utiliza trechos com gravação de guincho de dois porquinhos, "naturalmente afinados" em alturas diferentes, ". . . 'executados' por [Airto] Guimorvan [Moreira], proposta que Hermeto já tentou aplicar no Festival da Canção de 1972, no Maracanãzinho, em 72 , e quase o levou à cadeia" (MILLARCH, 1977). A ideia dos porcos retorna no Festival Abertura da Rede Globo de Televisão em 1975, quando Hermeto ganhou o prêmio de melhor arranjo com O Porco da Festa (MILLARCH, 1975).

COSTA-LIMA NETO $(1999,2000)$ aponta vários exemplos da relação que Hermeto faz entre as vozes dos animais e sua tradução atonal na partitura. Esse atonalismo "natural" ou ruidismo "ecológico" pode ser apreciado nos primeiros 16 compassos de Arapuá, incluída no disco Brasil universo (1986), em que um cluster no registro médiograve sobre uma $4^{\mathrm{a}}$ justa no baixo imita o zunido do tipo de abelha que dá nome à música (Ex.2; transcrição de Jovino Santos Neto, citado por COSTA-LIMA NETO, 2000, p.129). Já em Cores (disco Hermeto Paschoal e Grupo, 1982), cujo nome é uma referência ao arco-íris, às cigarras e aos amoladores de facas (COSTA-LIMA NETO, 1999, p.130), Hermeto utiliza o Lá de uma cigarra "gravada no jardim de sua casa" como um pedal agudo sobre dois pianos cuja somatória harmônica soa como um cluster (COSTA-LIMA NETO, 1999, p.140-142). Ainda em Cores, na coda, ele recorre a um cluster na região médio-aguda do piano para emular as "cores indefinidas" - parciais inarmônicos - de um pedaço de ferro sendo percutido (ou amolado) (Ex.2; transcrição de Jovino Santos Neto, citado por COSTA-LIMA NETO, 2000, p.136).

Se nos exemplos acima o atonalismo hermetiano resulta de uma abordagem vertical e homofônica, em Papagaio alegre (disco Lagoa da Canoa, Município de Arapiraca, 1984), é fruto da escrita linear e polifônica. Embora as vozes sejam baseadas individualmente em escalas diversas, o resultado sonoro de sua superposição polimodal não pode, auditivamente, ser considerado tonal, como mostra o trecho do Ex.3, que é uma redução da transcrição de Jovino Santos Neto do original para piccolo, saxofone tenor, piano e contrabaixo elétrico sobre uma gravação da fala do papagaio de Hermeto, chamado Floriano, em torno do registro de $\mathrm{Sib}_{3}$ (COSTA-LIMA NETO, 1999, p.151-161; COSTA-LIMA NETO, 2000, p.129).

A valorização dos sons de animais pode ter inspirado Hermeto em alternativas de utilização da voz que não a fala humana. Foi ele ". . . quem sugeriu que ela [Flora Purim] experimentasse improvisação vocal sem palavras. .." (McGOWAN e PASSANHA, 1999, p.167). Essa incorporação de uma grande variedade de efeitos vocais, como grunhidos, choros, rangidos, emulação de distorções eletrônicas, scatting aleatório e ondas de glissandi ajudou Flora Purim a vencer o prêmio de Melhor Cantora da Revista Down Beat por quatro vezes e ser nomeada duas vezes para o Grammy.

Ao descrever a Sinfonia do boiadeiro (1995), Hermeto recorre mais uma vez às vozes da natureza:

\begin{abstract}
"Você já viu uma boiada de 3 mil reses em movimento? Eu via e ainda vejo essas boiadas viajarem dois, três meses de uma fazenda para a outra, o vaqueiro tangendo, o gado atravessando o rio, o aboio, o barulhos dos cascos na água. É essa a sinfonia." (CABRAL, 2000, p.15)
\end{abstract}

\section{5 - Três princípios da Música Universal}

\author{
"A Harmonia é a mãe da música, o ritmo é o pai e a melodia ou o \\ tema é o filho" \\ "Bom gosto não se aprende na escola" \\ "A prática é quem manda" \\ Princípios da Música Universal de Hermeto Pascoal \\ (MORENA, 2008)
}

0 primeiro, o terceiro e o décimo-quarto princípios da música universal de Hermeto Pascoal, listados na epígrafe acima, sintetizam e norteiam o processo de formação de sua linguagem harmônica. Diferentemente de muitos músicos populares que, por não terem tido a oportunidade de estudar a música erudita, por isso criam, em torno dela, o mito de uma cultura superior e inatingivel, Hermeto Pascoal sempre encontrou caminhos alternativos diante dos impedimentos de uma educação formal em música que Ihe foram impostos. Ele relata: ". . . vim a aprender teoria com 42, 43 anos de idade. Eu memorizava muito as
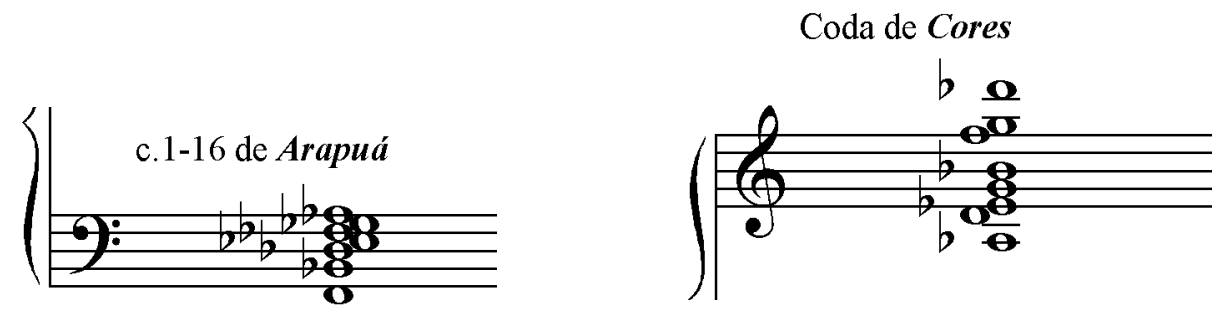

Ex.2 - Clusters imitando o zumbido da abelha arapuá na música Arapuá (transcrição de Jovino Santos Neto) e os parciais inarmônicos de um pedaço de ferro percutido na música Cores (transcrição de Jovino Santos Neto), ambas de Hermeto Pascoal. 


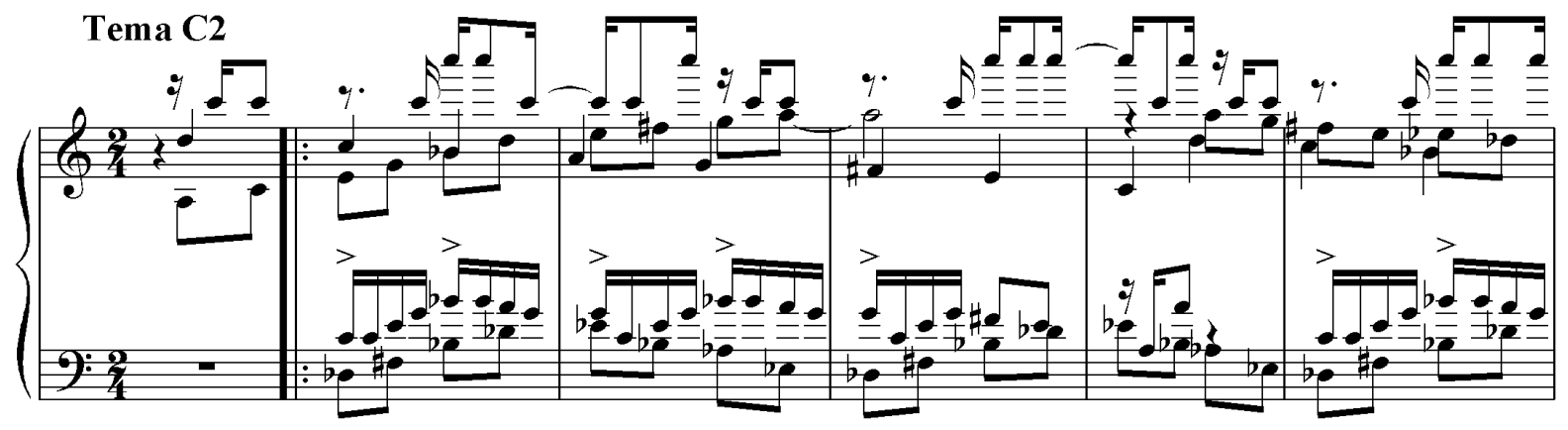

Ex.3 - Atonalismo resultante do contraponto polimodal em Papagaio alegre (transcrição de Jovino Santos Neto) de Hermeto Pascoal.

coisas. Quando eu viajava para São Paulo, mais ou menos uma hora de ônibus, ia cantando. Dava uma gorjeta ao cobrador e dizia: "Não sou doido, não sei música, não sei escrever e nem tenho gravador. Eu preciso ir cantando essa música até chegar na boate, até chegar no lugar em que eu toco". (CASTRO, SOUZA e ROCHA, 2007)

Percebe-se, ainda hoje, entre músicos, diletantes e leigos, o automatismo de associar sofisticação musical e formação erudita. Não é o caso de Hermeto, mas após quase 40 anos de profissão, ele viu-se atormentado com as frequentes perguntas de repórteres ávidos de saber sobre sua educação musical:

Quando fiz os meus 50 anos. . .eu falei para minha esposa Ilza. . estou um pouco preocupado, as pessoas estão cobrando muito de mim. . . eu não sei dizer como foi que eu aprendi. . . tão achando que eu estou escondendo alguma coisa. . .vocês acham que se alguém fosse meu professor não estaria feliz de ser meu professor, não seria conhecido?... não tenho um professor aparente. . . estou me sentindo órfão. . . aquele filho que nasceu e gostaria de conhecer os pais (CAVALCANTI, 2004).

A constatação de seu autodidatismo vitorioso e tão eficiente quanto qualquer formação acadêmica, entretanto, não implica em um desconhecimento de sua parte dos valores musicais mais racionais e menos intuitivos, característicos do músico letrado. Em Recife, Hermeto se maravilhava com os ensaios de Guerra-Peixe, ". . . mestre da arte da composição e do arranjo. . ." (VILLAÇA, 2007, p.36), e com o pianista Alberto Figueiredo, ". . . que tocava só Chopin. . . [que] lia a partitura e criava" (CAMPOS, 2006, p.81). A influência da música erudita aparece em algumas músicas do Calendário do som. Em 8 de dezembro de 1996 (PASCOAL, 2000a, p.211), Hermeto comenta tanto sobre a questão da harmonia, quanto a questão da técnica no piano: "Esta música é muito erudita e cheia de modulações. Até breve! Haja mão esquerda". Ainda refletindo uma prática erudita, somente esta música e mais quatro, em todo o livro, têm a mão esquerda realizada, com típicos gestos do pianismo romântico: repetidos arpejos em colcheias marcando as mudanças de harmonia e arpejos em quiálteras num jogo polirítmico de seis notas no acompanhamento contra quatro na melodia.
No Rio de Janeiro, admirava os ensaios do erudito-popular Radamés Gnattali. Com Edú Lobo, Hermeto, então pianista do Quarteto Novo, teve a oportunidade de conhecer metrópoles mundiais da música erudita na Europa e nos Estados Unidos. Um importante contato de Hermeto com partituras de música do século XX parece ter ocorrido ". .. em Los Angeles, o Edu [Lobo] ficava mostrando umas partituras do Stravinsky para ele. ...", embora Hermeto não considere muito o peso desta experiência na sua formação, pois ". . . Ah, eu não tava muito interessado nisso não." (entrevista de Jovino a COSTA-LIMA NETO, 1999, p.6). Mas o mesmo Hermeto, que em entrevista à Jazz Magazine em 1984 (citado por COSTA-LIMA NETO, 1999, p.4) disse: "Eu adoro tocar música 'clássica' ", certamente tocou muitas vezes a Pavane de G. Fauré, incluída no LP Brazilian Octopus (1969) e a ária Kein Wort do Segundo Ato da ópera A Flauta mágica de Mozart, incluida no mais recente CD/ DVD Chimarrão com Rapadura (2006). Sintomaticamente, sua parceria com Aline Morena, ". . . formada em canto lírico pela Universidade de Passo Fundo" (CASTRO, SOUZA e ROCHA, 2007), o motivou a compor para este último álbum uma música chamada $\dot{A}$ Capela.

Para descrever o estilo improvisatório de Hermeto, o crítico do The New York Times Stephen Holden fala mais de uma referência erudita do que do jazz norte-americano:

\footnotetext{
". . .ofereceu momentos de virtuosismo no piano, embora não faça exatamente aquilo que os americanos pensam a respeito do jazz. . . 'citações', improvisando em torno de standards da música americana - como Two for the Road (de Henry Mancini, composta em 1967 para a trilha do filme Um Caminho Para Dois), My Funny Valentine e Round Midnight. . . Poderia-se descrever seu som e estilo como uma lembrança e improvisação de Rachmaninoff com a força do fogo latino-americano". (MILLARCH, 1989a)
}

É muito provável que o contato com procedimentos da música erudita, diretamente com músicos de formação tradicional ou via outros estilos populares influenciados pela música erudita (como o jazz moderno), tenha inspirado Hermeto em harmonias e métricas mais complexas. 0 baterista Nenê conta que, como pianista do Quarteto Novo, Hermeto tocava "Garota de Ipanema em 7/4" (CAMPOS, 2006, p.109). Em Pintando o sete de Hermeto, 
a "... assimetria do compasso $7 / 8$ cria o efeito de estranhamento em relação à música popular convencional. .

. " (ARRAIS, 2006, p.12, 13). No "chorinho em sete" (um 7/4), que aparece na música $1^{\circ}$ de Fevereiro de 1977 do Calendário do som (CAMPOS, 2006, p.102), também se podem reconhecer diversos padrões assimétricos, como $[4 / 4+3 / 4],[2 / 4+2 / 4+6 / 8]$, mostrados no Ex.4, que não se relacionam com as métricas aditivas afro-brasileiras apontadas por SANDRONI (2001), mas provavelmente com uma leitura jazzística de práticas eruditas. Admirador de Radamés Gnattali, ícone da música brasileira que melhor integrou as músicas erudita e popular, Hermeto Ihe dedicou Mestre Radamés, música centrada em um complexo solo de bateria, cuja partitura revela "melodia de timbres", "frases ritmico-melódicas deslocadas", a "coexistência de diferentes pulsações", a "fusão e alternância de células rítmicas" e a ausência ou "poucas barras de compasso" (CAMPOS, 2006, p.120-121).

Ironicamente, os problemas crônicos enfrentados pelo músico erudito no Brasil podem ter favorecido Hermeto ter se cercado de instrumentistas de alto nível e com experiência sinfônica. As ". . . dificuldades profissionais da classe de instrumentistas - onde se incluem desde os músicos de sinfônica até os integrantes de bandas carnavalescas. .." de que falava Plínio Marcos, geraram (e têm gerado) uma desilusão, instabilidade profissional e, mesmo, provocado a evasão das orquestras, em grande parte devido à incompetência do ". . . sindicato, a Ordem dos Músicos ... nada fazem, nada reivindicam. .. " (BAHIANA,1979-1980b, p.78). COSTA-LIMA NETO (1999, p.72) lembra que ". . . com exceção do percussionista Pernambuco, os demais integrantes do Grupo [do Jabour] tiveram passagens pela música erudita e a abandonaram para se dedicar à música popular ... [formando um grupo] semelhante a um conjunto de música de câmara. . ." Márcio Bahia tocou na Orquestra Sinfônica do Teatro Municipal do Rio de Janeiro. Itiberê estudou piano clássico. Carlos Malta estudou na Escola de Música da UFRJ e na Escola de Música Villa-Lobos. Jovino, que hoje leciona no Cornish College of the Arts (Estados Unidos) no qual compositores avant-garde como John Cage, Joshua Kohl e Jarrad Powell foram compositores residentes, declarou a GILMAN (sem data) seu plano de re-orquestrar A sagração da primavera de Stravinsky para 10 músicos apenas.

Apesar de não ter tido professores eruditos, a proximidade de Hermeto com a música erudita é visível na suas obras sinfônicas que compôs, ainda muito pouco conhecidas, como Sinfonia em Quadrinhos; Sinfonia Berlim e sua gente; Suite Pixitotinha; Suite Paulistana; Suite Mundo Grande; Suite Norte, Sul, Leste, Oeste; Sinfonia Vale do Ribeira e Sinfonia do Boiadeiro. Um dos ícones da música erudita brasileira, Isaac Karabtchevsky, quando o regeu à frente da Orquestra Jovem de São Paulo no Teatro Municipal, não economizou elogios: "Ele sempre me impressionou pelo domínio instrumental aliado a uma inventividade rítmica e melódica, que engloba uma visão de todos os sons num resultado fantástico" (COMODO, 1996).

Mas Hermeto não reteve as terminologias eruditas, as regras formais e harmônicas, preferindo se guiar pelo resultado da realização musical, pelas sonoridades que diziam respeito à sua percepção e pelo vocabulário próprio da aprendizagem oral. Daí surgiram termos como "cacho de uva" (acordes), "três andares" (superposição de três acordes) (ZWARG, 2009b), "garfinho" (síncope), "pendurada" (acento contramétrico), "chão" ou "fora do chão" (ênfase nos tempos ou contratempos), "quebrar" (sair da ênfase nos tempos) (CAMPOS, 2006, p.86-87). Não estar preso à formação tradicional de música também lhe permitiu criar conceitos mais amplos como música universal, cifragem universal, música da aura, música dos ferros e utilizar o método do corpo presente, criado por Itiberê Zwarg (MORENA, 2009).

Favorecendo a prática, e não a teoria, na sua rotina musical, Hermeto alcançou um nível criativo em que a improvisação tornou-se muito próxima da composição, ao mesmo tempo fluente, em tempo real e com extraordinária riqueza de ideias:

"A surpreendente originalidade dessas ideias e a grande variedade de procedimentos composicionais empregados, resultam em improvisações extremamente bem concebidas e finalizadas, podendo
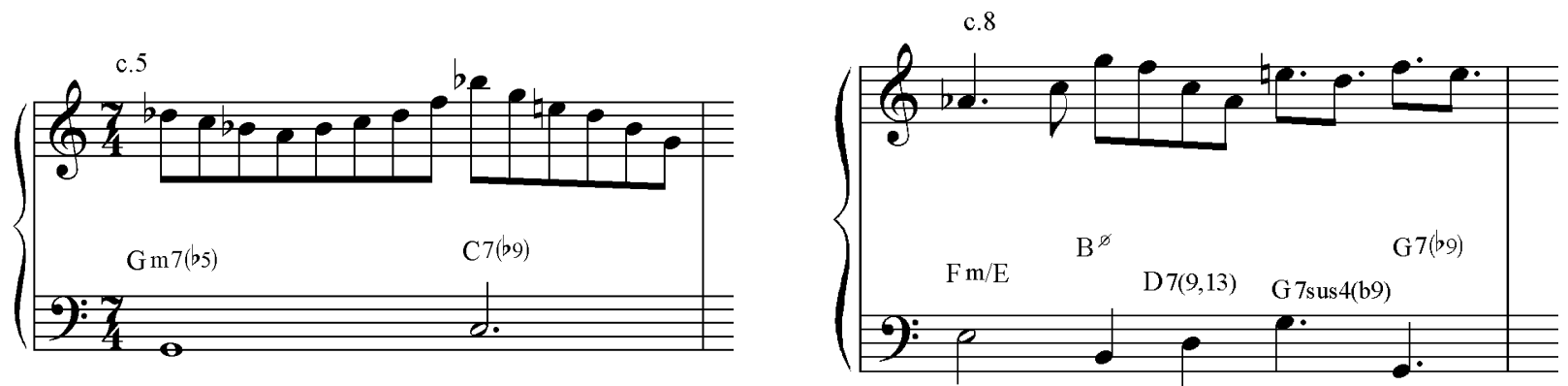

Ex.4 - Padrões de $[4 / 4+3 / 4]$ e $[2 / 4+2 / 4+6 / 8]$ na métrica $7 / 4$ em $1^{\circ}$ de Fevereiro de 1977 de Hermeto Pascoal. 
ser ouvidas e estudadas independentemente de seus temas de origem, demonstrando complexidade e nível artístico de composições previamente elaboradas PRANDINI (1996, p.91)

Da mesma forma, a diversidade harmônica que se encontra nas composições de Hermeto também parece estar presente em suas improvisações e é fruto de sua abordagem, como relata Jovino: "É necessário compor e escrever como se fosse improviso e tocar como se fosse escrito" (COSTALIMA NETO, 1999, p.23). Após analisar alguns solos improvisados no período entre 1985 e 1992, José Carlos Prandini observou a existência de padrões que dão unidade à sua música criada espontaneamente. Embora tenha utilizado uma amostragem pequena e tenha simplificado a harmonia de Hermeto nas suas transcrições e grafia, PRANDINI (1996, p.89-90, p.4 da segunda partitura do Anexo I) fala da improvisação de Hermeto como um frequente "grande adensamento de notas", com predomínio de semicolheias, tercinas e fusas dentro de um "pensamento diatônico" junto com os quais podem aparecer a fixação em um acorde apenas, uma preferência pelas escalas Lídia, Superlócria e Dórica (e, em menor grau, a escalas Menor melódica, Mixolídia e Tons inteiros). Mas observa também que ocorrem "... superposições de elementos originários de outras áreas tonais, ou emprego de tonalidade expandida..." e, mesmo, "fala e ruído de animais", como ocorre ao final da improvisação em 0 Tocador quer beber.

A orientação pela prática, e não pela teoria, permitiu ao discípulo Itiberê Zwarg, "herdeiro" das práticas musicais de Hermeto no Jabour, desenvolver o conceito de método do corpo presente, no qual a composição e a performance são processos quase simultâneos e participativos, característica fundamental no processo criativo e coletivo da Itiberê Orquestra Família. Ele explica:

\footnotetext{
“. . As músicas vão surgindo segundo o método de corpo presente. a capacidade de compor na hora, burilando as músicas ali no contato com os instrumentistas. . . 0 que sai dessas reuniões de corpo presente é delirantemente variado. Em Pedra do Espia há chorinho, forró, samba, valsa e muito mais. Tudo 100\% instrumental. . Partimos do som, da referência auditiva, ao invés do método tradicional - que usa a visão, o olhar cravado na partitura. As músicas amadurecem muito rápido. Ensaiamos muito. .." (BARBOSA, 2001)

\begin{abstract}
"Conforme vou compondo, em um instrumento qualquer,a música vai sendo executada quase simultaneamente à sua criação. Por exemplo: faço uma frase melódica e passo para o clarinetista; a harmonia para o pianista; e em seguida vou abrindo as vozes para todos os instrumentistas, parte por parte. . Reproduzir de ouvido o que vou criando desenvolve a percepção rítmica, melódica, harmônica e a memória musical. . a memória de cada um dos músicos é acionada pelo estímulo do som e não pelo estimulo gráfico. Só depois de parte da composição e arranjos prontos é que cada um dos instrumentistas com a ajuda de meu monitor, escreve o que executou, desenvolvendo a habilidade da escrita musical. . . aprendem a escutar todos os instrumentos, presenciando [grifo nosso] e participando de todo o processo de criação." (ZWARG, 2009c)
\end{abstract}

Jovino procura explicar as raízes do conceito harmônico de Hermeto, os quais aprendeu na Escola Jabour e levou para o exterior:

É sempre difícil explicar os conceitos harmônicos de Hermeto, mesmo para outros músicos. . . ele disse que costumava, na infância, ficar na oficina do avô ferreiro. . . batia na peças de ferro e tentava emular todos os harmônicos que ouvia no seu fole de oito baixos. . . ele não segue as progressões harmônicas usuais, por isso, soa sempre novo e inesperado. . embora seus acordes sejam bastante elaborados, são, na maioria, formados por triades simples empilhadas umas sobre as outras. .. o que é radicalmente diferente do que é ensinado na maioria das escolas. Isto nos dá a oportunidade de criar música sem ser baseada na utilização de escalas e modos. Tenho mostrado este conceito aos meus alunos aqui na [Escola de Música do] Cornish College of the Arts em Seattle [Estados Unidos] e é surpreendente como reagem quando descobrem que simples acordes podem criar harmonias complexas (GILMAN, 2009)

Na música De bandeja e tudo, COSTA-LIMA NETO (1999, p.148) reconhece ecos modais e sonoridades de ". . . efeito imponente, solene e místico" resultantes dos acordes com quartas e quintas justas sem terças, os quais normalmente se associam, na música erudita, desde os organa medievais, até as quintas diretas dos power chords do rock, passando pelas harmonias paralelas de Debussy. Novamente, e apesar da possibilidade de Hermeto ter ouvido estas referências na sua vida de músico profissional maduro entre músicos letrados, é mais provável que estas sonoridades tenham surgido na sua música mais a partir da conformação de suas mãos sobre os instrumentos (sanfonas e teclados, como o recorrente acorde X4568) e mesmo, do modalismo típico nordestino, remanescente dos trovadores renascentistas, que José SIQUEIRA (1981) identificou no seu Sistema Modal na música folclórica do Brasil.

Outro recurso de complexidade harmônica comum em Hermeto, oriundo das exaustivas práticas de ensaio diárias e não da teoria, é o dobramento da mesma linha melódica por outro instrumento transpositor sem se preocupar em manter a mesma tonalidade COSTA-LIMA NETO (1999, p.150), superposição que, obviamente, terá o mesmo efeito prático da politonalidade.

0 contraponto, um elemento típico da música erudita, pertence ao vocabulário de Hermeto desde o início de sua carreira. Na gravação do disco Brazilian Octopus (1969), bolou uma linha contrapontística para duas flautas para acompanhar o repetitivo tema da música $O$ Pássaro do guitarrista Lanny Gordim. 0 saxofonista Carlos Alberto relata a importância que Hermeto confere à sofisticação de sua criação musical: "Só que, na hora da mixagem, o contracanto tinha sumido da gravação. 0 Hermeto ficou tão bravo que queria pegar o técnico. .."(CALAD0, 2000). Muitas vezes, ele deixa claro seu pensamento contrapontístico nas partituras, como na música 10 de setembro de 1996 do Calendário do som, inspirada em Tom Jobim (PASCOAL, 2000a, p.102). Mas a simultaneidade de linhas melódicas na música de Hermeto não parece derivar de suas experiências com música erudita mas, antes, podem remeter às experiência sonoras de sua infância, muitas vezes complexas. Por exemplo, a superposição de materiais desconectados, gerando a sensação de caos pela simultaneidade de diversas pulsações, andamentos e atmosferas é relatada por ele mesmo, ". . . [na feira de Lagoa da Canoa, em que] haviam os cantadores de embolada, os vendedores anunciando, os discos do Luiz Gonzaga tocando no megafone. . . e era tudo isso junto, de uma vez só. . . ", o que pode ter servido de modelo para ele na ". . bandinha da escola, na 
qual tocava tambor. . . atravessado de propósito para ver a marcha ficar trocada. .. " (CAMPOS, 2006, p.134).

Uma das características do estilo composicional de Hermeto Pascoal é a economia de meios na utilização do vocabulário harmônico. Geralmente ele recorre à repetição dos mesmos tipos de acordes e a transposições de encadeamentos harmônicos (sequências), tanto em obras mais antigas quanto mais recentes. Mais do que isto, em muitas músicas, a predominância de um tipo de acorde sobre os demais é muito comum. Por exemplo, no manuscrito do compositor de 0 Ovo (PASCOAL, 2008), peça gravada pela primeira vez no disco Quarteto Novo (1967), nota-se que a recorrência de acordes do tipo X4568 / 4 ocupa 75,6 \% dos 45 acordes da peça. Já em Amor, paz e esperança (PASCOAL, 1980), os acordes menores do tipo Xm479 correspondem a $48,8 \%$ e os acordes do tipo X479 correspondem a $29,2 \%$ do total de 41 acordes da peça (juntas, essas versões maior e menor deste acorde equivalem a $78 \%$ do conteúdo harmônico utilizado!).

A economia de meios é ainda mais evidente em 22 de agosto de 1996, que ele diz ter composto "com um tipo de acorde, só com modulações" (PASCOAL, 2000a, p.83). Aqui, ele recorre mais uma vez ao típico acorde $X 4568$ (sem terça, com 4a $5^{\mathrm{a}}, 6^{\mathrm{a}}$ e reforço da oitava). Estão claros os dois procedimentos nos quais Hermeto se baseou para compor os encadeamentos harmônicos desta música: 0 mesmo tipo de acorde com fundamentais diferentes, mas sobre o mesmo baixo (como nos c.9-10: Bb 4568/F, Ab 4568/F, G 4568/F, Eb 4568/F) e, esporadicamente, o mesmo tipo de acorde com a mesma fundamental, mas sobre baixos diferentes (como no c.13: B 4568/D\#, B 4568/D). A genialidade harmônica de Hermeto fica evidente com a solução encontrada para sua concepção planejada para a música 12 de novembro de 1996, que ele descreve assim: "compus esta música nos doze tons, maiores e menores" (PASCOAL, 2000a, p.165). Como se fosse um Bach da música popular do século $X X$, ele consegue concentrar, em apenas 24 compassos contendo uma cifra cada, um passeio "bem-temperado" por todos os acordes das tônicas dos 24 tons maiores e menores, baseando-se em apenas dois tipos de acorde (X7+ e Xm 479). Desta forma, consegue utilizar uma variedade máxima de acordes, sem perder a coerência do discurso tonal tradicional da música popular. Tal coerência poderia ser explicada alternativamente como ambiguidades ou polarizações em torno da tônica e da supertônica, ao invés de configurar modulações (Ex.5).

Avesso a rótulos, Hermeto precisou criar um para dar conta da diversidade que é o princípio básico de seu conceito de música universal, no qual cabem ". . . todos os estilos e todas as tendências. 0 Brasil, sendo o país mais colonizado do mundo, não poderia ser outra coisa . . . aquela mistura bem feita ...", como afirmou em uma entrevista à revista eletrônica Jungle Drums (citado por ARRAIS, 2006, p.7). Este conceito torna a música uma experiência mais ampla do que apenas o fazer musical. COSTA-LIMA NETO (2008, p.24-25) identifica na música universal opções de estilo de vida, como "arte" e "qualidade", em oposição a "dinheiro" e "quantidade". De fato, o documento com dezessete Princípios da Música Universal criada por Hermeto Pascoal, organizado pela discípula a atual esposa Aline MORENA (2008), é visionário e valoriza atitudes como ". . . amar, criar, imaginar e se inspirar nos sons da natureza. . . misturar sem preconceitos, mas com bom gosto. . . são todos os mundos. . . só busca encontrar-se. . . a confraternização e o amor entre os povos. . . é alimento para a alma".
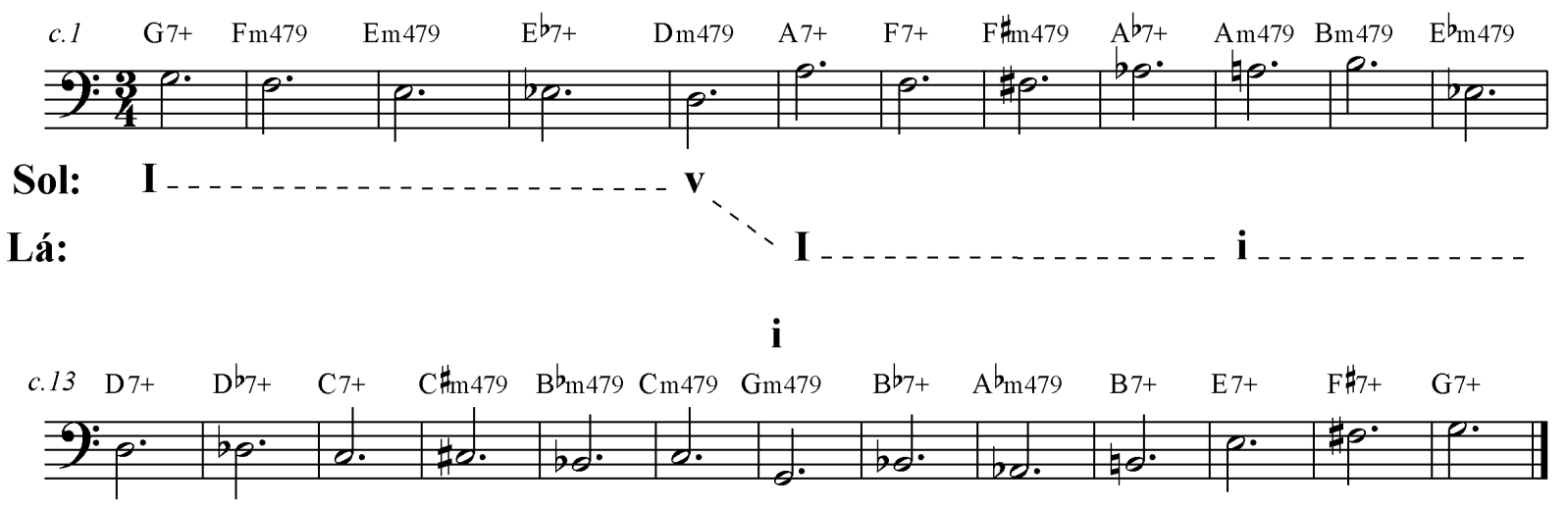

Sol: iv $\ldots$ i

Lá:- - IV

Ex.5 - Economia de meios harmônicos, máxima variedade de acordes e ambiguidade tonal de Hermeto Pascoal na música 12 e novembro de 1996. 


\section{6 - Hermeto Pascoal: "Minha religião é a música" (GONTIJO, 2000, p.2)}

"Eu rezo com a música, com o instrumento". Hermeto Pascoal (0. RODRIGUES, 2003)

A religião, especialmente aquela dos ritos populares brasileiros, sempre fez parte do mundo musical de Hermeto Pascoal. As experiências religiosas estão presentes desde sua infância em Lagoa da Canoa, nas procissões dos benditos e nas rezas das novenas (CAMPOS, 2006, p.69), nos mistérios das crenças, que ele mesmo relata: "Com 8 anos, achava que era alma, mas não era nada mais do que os morcegos dentro da igreja" (CASTRO, SOUZA e ROCHA, 2007). A religiosidade de Hermeto aparece nos títulos de muitas músicas, como Velório (disco Hermeto, 1971; relançado em CD como Hermeto Pascoal, Brazilian adventure), Religiosidade (disco Cérebro Magnético, 1980), Novena (disco Hermeto Pascoal e Grupo, 1982), Santo Antônio (disco Zabumbê-bum-á, 1979), São Jorge (disco Zabumbê-bum-á, 1979), Santa Catarina (1984), Monte Santo (disco Lagoa da Canoa, município de Arapiraca,1984), Mentalizando a cruz (disco Brasil Universo, 1985), Magimani Sagei (disco,1982), Missa dos escravos (disco Slaves Mass, 1977), Igrejinha (gravada como Little church no disco Live evil de Miles Davis), Devoção, Mestre Mará (1979), 25 de dezembro de 1996 do Calendário do som (dedicada a Jesus), 16 de março de 1997 do Calendário do som (dedicada ao médium espírita Doutor Fritz e seus irmãos espirituais), entre outras.

Falando da "cosmologia pessoal" de Hermeto Pascoal, COSTA-LIMA NETO (2010a), acredita que o Calendário do som (2000) é "uma obra sacra 'inspirada por Deus'". Ou Deuses. Ecumênico, Hermeto está atento às tradições religiosas indígenas e afro-brasileiras. No processo de gravação de Magimani Sagei (1982), música com clima de dança tribal que se refere à índia cabocla Magimani Sagei (um possivel "alter-ego de Hermeto"), e que tem correspondência com uma alta entidade espiritual na umbanda:

\begin{abstract}
". . . o técnico de estúdio Zé Luiz inventou, a pedido de Hermeto, palavras com sonoridade tupi ("oirê, ogorecotara, tanajura"), enquanto, nos breques instrumentais, os músicos falavam palavras desconexas, sopravam apitos e gritavam. Os latidos dos cachorros Spock, Bolão e Princesa adensavam a textura geral, enquanto 0 andamento acelerava até o final free, improvisado" (COSTA-LIMA NETO, 2008, p.10).
\end{abstract}

Em Missa dos escravos, incluída no disco Slaves Mass, pode-se observar novamente a voz como elemento típico da música ritualística:

"A frase cantada 'Chama Zabelê pra poder te conhecer' é entoada hipnoticamente num crescendo, em uma mesma nota grave contínua, como em um recitativo (recto tono) de uma missa católica medieval, acompanhada pelo naipe dissonante de flautas e tendo como base os batuques dançantes dos tambores da bateria. No final, um duo de porcos grunhindo dialoga com o solo vocal de gargalhadas, choro e gritos de Flora Purim, superpostos a uma melodia lenta tocada na flauta transversa em unissono com a voz cantada, aparentemente inspirada nos cantos de rezadeiras e nos benditos e incelenças do catolicismo popular nordestino (COSTALIMA NETO, 2008, p.11).
Em outro exemplo do sincretismo afro-indígena no Brasil, Hermeto recorre a ". . . recursos vocais não convencionais, como sussurros, chiados, glissandi, ataques glotais, tosse, gritos" para criar a ambiência afro-brasileira de Mestre Mará (1979), e uma série de aliterações com palavras em torno do título:

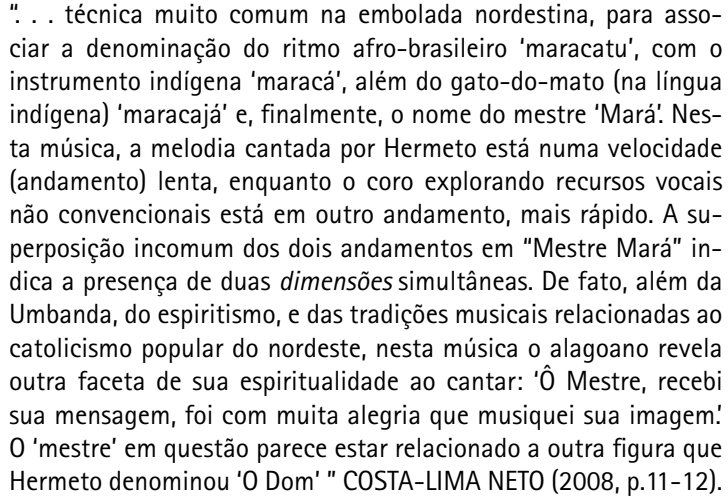

0 jornalista Howard Mandel, da revista Down Beat, o compara com outras referências místico-musicais: ". . . Pascoal é um líder pan-global como [o compositor e pianista de jazz, poeta, filósofo, pioneiro da filosofia cósmica afro-futurismo] Sun Ra e um individualista como [o multi-instrumentista e militante Afro-Americano] Rashaan Roland Kirk " (McGOWAN e PASSANHA, 1999, p.161). Mesmo os músicos estrangeiros e que tiveram pouco contato com Hermeto percebem a religiosidade com que ele abraça a música. Lyle Mays, tecladista do Pat Metheny Group diz que "Ele tem uma verdadeira devoção com o fazer musical, e nos expressa isto..." (McGOWAN e PESSANHA, 1991, p.160).

A música parece, de fato, ser um instrumento religioso de comunicação para Hermeto. A amizade que estabeleceu com Miles Davis refletiu-se na música de Hermeto muito tempo após a morte do jazzista norte-americano, ao lhe dedicar a música Capelinha e lembranças (disco Eu e eles, 1999):

\footnotetext{
"Essa música com o Miles foi o seguinte. . . aconteceu agora, depois dele lá no outro plano. .. por ser um gênio, um cara tão musical, ele aprendeu essas músicas minhas [Little church e Nem um talvez no disco Live evil de Miles Davis], eu não precisei escrever partitura nem nada. . . Ele aprendeu gravando essas músicas no estúdio, e ficou. E eu tocando o Hammond. . . tocando num órgão elétrico que ele tinha lá, horrivel. . . aumentei o volume e o som veio pela intuição. .. Uáaa, Uáaaa. . . Ai o Miles correu de lá e disse: 'Oh, que som, que coisa bonita isso aí.' Então nesse meu disco agora, que eu fiz essa música e dediquei a ele. . . [para] retribuir. . . aquele convite que ele fez no disco dele [que] ... me comunicando muito com ele espiritualmente. Comecei a tocar e sentia muito a presença dele na minha mente. .. Na gravação é que estava muito mais forte a intuição. . . que começa a capella. . . com os quatro flugelhorns. .. eu conversando com ele, brincando com ele. .. tocando samba no flugelhorn. . . colocaram como se fossem duas músicas, não são duas músicas, aquilo é uma música só. Aquilo é a introdução da melodia" (BARROSO, 2009)
}

Hermeto, ecumênico, admira a doutrina espírita, religião escolhida por muitos familiares de sua primeira esposa, Dona Ilza. Ele diz: "Eu vivi nesse meio e tenho muita experiência que o pai dela passou pra mim sobre 
Alan Kardec, mesa branca. Você não vê, por exemplo, ninguém de Alan Kardec na TV pegando dinheiro, vê?" (0. RODRIGUES, 2003).

Uma escuta atenta da música Chapéu de baeta (disco Festa dos deuses, 1992 ) revela Hermeto recitando sobre ". . . o som que embala a alma. . . quem premedita não procura e jamais encontra . . .é sair com fé, coragem, com muita meditação. .." Já em Mentalizando a cruz, no longo trecho de piano solo que inicia a música, COSTA-LIMA NETO (2008, p.11) diz que ". . f foi composta por Hermeto e dedicada ao músico Paulo Cesar Wilcox" e que "Hermeto parecia convencido que o homenageado, recém-falecido, teria 'soprado' esta música aos seus ouvidos, como numa psicografia."

A linguagem atonal geralmente aparece na música de Hermeto Pascoal como música da aura, em que "meu ouvido absoluto, recebe os fenômenos sonoros cotidianos. 0 familiar é tornado exótico e vice-versa. . ." motivada por emulação de sons de altura não definida como a fala humana (como em Aula de Natação, na qual ". . . transpõe as diferentes durações e alturas da voz falada em prosa para o piano, resultando uma melodia totalmente atonal e de ritmo assimétrico" (COSTA-LIMA NETO, 1999, p.176) ou o som percutido de peças de metal de natureza programática como em Ferragens.

Em Canon para flauta solo, gravada no disco Slaves Mass por Hermeto PASCOAL (1977), a sua religiosidade tornase explícita na intenção de emular uma sessão musical espírita no estúdio de gravação e se comunicar como o colega jazzista Julian "Cannonball" Adderley (19281976), recém-falecido. Uma análise da gravação e das partituras (veja a partitura original desenhada em forma de espiral no presente número de Per Musi [PASCOAL e PEREIRA, 1977, p.70] e a partitura restaurada [PASCOAL e BORÉM, p.80-82, nesse volume de Per Musi.]), revela uma utilização expandida da linguagem harmônica modal. Em Cannon, Hermeto alterna um modalismo extremamente instável, sem centros modais definidos (que, por isso, pode ser percebido como quase-atonal), com polarizações modais (Sol Dórico/Eólio e, depois, Sol Eólio/Menor Melódico) que sugerem as etapas de uma sessão espírita: o contato, o transe, a incorporação espiritual, e a despedida com a alma de "Cannonball" (BORÉM e FREIRE, 2010; veja artigo completo às p.63-79 no presente volume de Per Musi).

Sempre que the perguntam sobre religião, entretanto, Hermeto diz que "Minha religião é a música. Deus me disse: 'A religião de vocês aí, meu filho, é o trabalho. É o que vocês gostam de fazer na vida' " (GONTIJO, 2000, p.2). Não é algo separado das atividades do dia-a-dia. Este interesse nas tarefas comuns e trabalho dos que cercam Hermeto também se reflete nos títulos de suas músicas, como Ilza na feijoada, em que faz referência à atividade da esposa desde seus tempos no Recife, ou Aula de natação que retrata a lida diária da filha Fabíula Pascoal, formada em educação física.
Aos poucos, o culto à música por Hermeto e seus seguidores tem tomado a forma de um local público que abrigará, segundo sua esposa e parceira musical Aline Morena, ". . . um teatro, que terá o acervo do Hermeto, uma sala onde haverá o acervo multimídia. Além de acontecerem espetáculos de música universal, vão estar disponíveis os vídeos de shows, de workshops." (CASTRO, SOUZA e ROCHA, 2007). 0 Templo do Som Hermeto Pascoal, cujo projeto arquitetônico ". . . já está pronto e é assinado pelo arquiteto Mário Biselli" será um espaço que, além de disponibilizar manuscritos originais, gravações raras e imagens, terá uma função educacional, onde pretende-se a discussão sobre música e seu papel na melhoria do ser humano (PAULA, 2007). Hermeto parece preparado para deixar o legado de sua missão na terra:

"...Deus fez uma escada infinita e a deu de presente a cada um de
nós. Estou subindo os degraus e vou continuar subindo. Não é pre-
ciso olhar para trás, porque a vida já é um espelho." (CASTRO, SOU-
ZA e ROCHA, 2007); "Tudo o que sei e serei agradeço a Deus, aos
Deuses e ao meu dom espiritual e musical". (PASCOAL, 2000b, p.18)

\section{7 - Considerações finais}

Ouvidos desatentos às experiências de vida de Hermeto Pascoal podem reconhecer, dentro do seu eclético estilo composicional, ecos derivados diretamente de estilos eruditos, como melodias acompanhadas chopinianas; acordes paralelos debussynianos; os contrapontos, superposições politonais e emancipação rítmica de Stravinsky; os clusters atonais da segunda escola de Viena; as superposições métricas e harmônicas de Charles Ives; a complexidade rítmica de Boulez; as transcrições de Messiaen de sons da natureza para o piano; as paisagens sonoras de R. Murray Schafer; as manipulações eletroacústicas remanescentes de Pierre Schaeffer e Pierre Henry; os ruidismo musicais de Luigi Russolo; a música conceitual de John Cage; e, mesmo, os modelos modais de composição e de improvisação oriundos do jazz.

Entretanto, basta acompanharmos a trajetória musical deste músico genial, para o qual não existe divisão entre composição, performance, arranjo e improvisação, para reconhecermos, já na sua infância, as premissas da economia política da música de Jacques Attali que COSTA-LIMA NETO (1999, p.42-43) identifica em Hermeto Pascoal: o "espelho do tempo e da sociedade", a "ação crítica", o "atributo do poder político e religioso" e o "germe da revolta".

No caso de Hermeto, ". . . a tendência em buscar referências musicais ao mesmo tempo consagradas e generalizantes (música erudita, jazz). . ." (CAMPOS, 2006, p.78) não se aplica. Embora seus ouvidos de "gravador infinito" estiveram (e estão) literalmente atentos a todos os sons que o cercaram, inclusive os eruditos, seu processo de aprendizagem é único - resultado de suas experiências de vida musicais e não-musicais - e centrado na transmissão oral do conhecimento. 0 caminho é outro, não tradicional, não-letrado, autodidata, mas os resultados sonoros não ficam aquém daqueles do tonalismo, mo- 
dalismo, atonalismo, polimodalismo, paisagem sonora e música concreta da música erudita.

Espera-se que este estudo de caso sobre Hermeto Pascoal possa servir de ponto de partida para estudos posteriores, quiçá aqueles de natureza indutiva que, a partir da análise de um conjunto maior de músicas desse compositor genial, possam revelar mais detalhes sobre seu estilo composicional, especialmente seus percursos harmônicos.

Respondendo ao jornalista Álvaro Cavalcanti da Radio Nederland Wereldomroep sobre o encontro entre o tradicional e a vanguarda na música, Hermeto disse que " $A$ música para mim, não há como falar em vanguarda, falar em jazz, falar em baião, falar em chorinho. . . não tenho rótulos" e, mais à frente, sobre mesmice e variedade em música, ". . . o povo cansa de uma coisa só. ... ." (CAVALCANTI, 2004). 0 "tacho de sons" no qual CAMPOS (2006) descreve como os ritmos se misturam "tudo de uma vez só" é o mesmo no qual Hermeto Pascoal experimenta suas receitas em que cabem todos os ingredientes harmônicos, muitas vezes "tudo de uma vez só". Do alto de suas experiências de vida e maturidade musical, o sempre inusitado Hermeto Pascoal reflete, sem falsa modéstia, sobre si mesmo: ". . . naquele tempo eu era lindo e agora sou um santo." (TÁRIK DE SOUZA, 1990).

\section{Referências:}

ALBIN, Cravo. Hermeto Pascoal. In: Dicionário Cravo Albin da música popular brasileira. 2009 www.dicionariompb.com. br. Acesso em 10 de fevereiro, 2009).

ARAÚJO COSTA, Fabiano. Análise e realização de 4 lead sheets do Calendário do Som de Hermeto Pascoal segundo os conceitos harmônicos de Arnold Schoenberg. Belo Horizonte: UFMG, 2006 (Dissertação de Mestrado).

ARRAIS, Marcos. A música de Hermeto Pascoal, uma abordagem semiótica. São Paulo: USP, 2006 (Dissertação de Mestrado).

AUGUSTO, Sérgio. 1971-1976, Tom era um homem em comunhão. In: Cancioneiro Jobim, 1971-1982. v.4. Músicas de Tom Jobim, arranjos de Paulo Jobim, apresentação de Paulo Jobim, desenhos de Elizabeth Jobim, tradução de Paulo Henriques Britto. Rio de Janeiro: Jobim Music/Casa da Palavra, 2000.

BAHIANA, Ana Maria. A "linha evolutiva" prossegue: a música dos universitários. In: Anos 70: 1 - Música popular. Org. Adauto Novaes. Rio de Janeiro: Europa, 1979-1980a.

Música instrumental: o caminho do improviso à brasileira. In: Anos 70: 1 - Música popular. Org. Adauto Novaes. Rio de Janeiro: Europa, 1979-1980b.

BARBOSA, Marco Antonio. Itiberê Zwarg e a herança de Hermeto Paschoal. Cybernotas. (Artigo publicado em 2 de novembro de 2001). In: www.cliquemusic.uol.com.br (Acesso em 7 de janeiro, 2009).

0 forró de Hermeto Paschoal. Cybernotas. (Artigo publicado em 6 de julho, 2001). In: www.cliquemusic.uol.com. br (Acesso em 7 de janeiro de 2009).

BARROSO, Fabiano et al. Nunca falei não, eu falo agora, agora eu falo: Hermeto Pascoal. Graffiti 76\% Quadrinhos. 2009. In: www.graffiti76.com/entrevistas.html. (Acesso em 6 de fevereiro, 2009).

BORÉM, Fausto; FREIRE, Maurício. Cannon de Hermeto Pascoal: aspectos musicais e religiosos em uma obra-prima para flauta. Per Musi, n.22. Belo Horizonte: UFMG, 2010, p.63-79.

CABRAL, Sérgio. Antônio Carlos Jobim: uma biogafia. 2ed. Rio de Janeiro: Lumiar, 1997.

. Hermeto Pascoal, um caso à parte. In: Calendário do som. Hermeto Pascoal. Ed. A. P. Quartim de Moraes. Hermeto Pascoal. São Paulo: SENAC São Paulo, 2000.

CALADO, Carlos. A estranha saga do Brazilian Octopus. Cybernotas. 2000 (Artigo publicado em 24 de novembro, 2000). In: www.cliquemusic.uol.com.br (Acesso em 7 de janeiro de 2009).

Após 11 anos de recesso, músico alagoano não quer mais gravar com grandes gravadoras nem com figurões da MPB. Folha de São Paulo. Folha Ilustrada. São Paulo, terça-feira, 11 de março de 2003.

CAMPOS, Lucia Pompeu de Freitas Campos. Tudo isso junto de uma vez só: o choro, o forró e as bandas de pífano na música de Hermeto Pascoal. Belo Horizonte: UFMG 2006 (Dissertação de Mestrado).

CARDOSO, Tom. Escritor prepara biografia de Hermeto Pascoal. Cybernotas. (Artigo publicado em 18 de agosto, 2000). In: www.cliquemusic.uol.com.br (Acesso em 7 de janeiro, 2009).

CASTRO, Nana Vaz de. Hermeto, o alquimista sonoro de todas as emoções. Cybernotas. (Artigo publicado em 21 de novembro, 2000). In: www.cliquemusic.uol.com.br (Acesso em 7 de janeiro, 2009). 
CASTRO, Pedro Jorge de; SOUZA, Giovani de; ROCHA, Fabrício. Hermeto Pascoal, música de tudo e para todos. Jornal da Câmara. Brasilia, 7 de maio, 2007. Ano 8 n.1824. In: http://www.camara.gov.br. (Transcrição de entrevista para a TV Câmara, acesso em 9 de janeiro, 2009).

CAVALCANTI, Álvaro. Entrevista de Hermeto Pascoal à Radio Nederland Wereldomroep. In: Raízes musicais brasileiras: tradição e inovação. Apresentação de Álvaro Cavalcanti, locução de Anna Luiza Moreira, técnicos de som John Nieuwenhuis e Arjan de Reus. v.4. Hilversum, Holanda: Radio Nederland Wereldomroep, 23 de fevereiro, 2004 (CD quádruplo).

COMODO, Roberto. Alquimista sonoro: Hermeto Pascoal escreve ópera e apresenta uma suite sinfônica para comemorar seus 60 anos. Isto é. 17 de abril, 1996. In: www.terra.com.br/istoe (Acesso em 12 de janeiro, 2009).

COSTA-LIMA NETO, Luiz. A música experimental de Hermeto Pascoal e Grupo (1981-1993): concepção e linguagem. Rio de Janeiro: Unirio, 1999. (Dissertação de Mestrado). http://teses.musicodobrasil.com.br/a-musica-experimental-dehermeto-pascoal-e-grupo.pdf. [Disponivel em inglês como "The experimental music of Hermeto Pascoal and Group (1981-1993): conception and language": http://teses.musicodobrasil.com.br/luiz-costa-lima-the-experimental-musicof-hermeto-pascoal-and-group.pdf in Músicos do Brasil: Uma Enciclopédia Instrumental . http://www.musicosdobrasil. com.br/inicio.jsf , 2009.]

Da casa de Tia Ciata à casa da Família Hermeto Pascoal no bairro do Jabour: tradição e pós-modernidade na vida e na música de um compositor popular experimental no Brasil. Música \& Cultura, revista on-line de etnomusicologia. n.3. Salvador: UFBA, 2008. [(www.musicaecultura.ufba.br, acesso em 9 de janeiro, 2009). Disponivel em inglês como "From the house of Tia Ciata to the house of the Hermeto Pascoal Family in Jabour: tradition and post-modernity in the life and music of a popular experimental composer in Brazil": http://ensaios.musicodobrasil.com.br/luizcostalimanetotraditionandpostmodernity-hermeto-pascoal.pdf in Músicos do Brasil: Uma Enciclopédia Instrumental. http://www.musicosdobrasil.com.br/inicio.jsf , 2009.]

0 Calendário do Som e a estética sociomusical inclusiva de Hermeto Pascoal: emboladas, polifonias e fusões paradoxais. Revista USP. n.82. São Paulo: USP, 2010a.

0 cantor Hermeto Pascoal: a voz como instrumento. Per Musi, n.22, p.44-62. Belo Horizonte: UFMG, $2010 b$.

The experimental music of Hermeto Paschoal e Grupo (1981-93): a musical system in the making. British Journal of Ethnomusicology. Brazilian musics, Brazilian identities. Ed. Suzel Ana Reily e Martin Clayton. Cambridge, England.v.9/i, 2000, p.119-142. http://www.open.ac.uk/Arts/music/mclayton/bje9-1 finalpdf.PDF

ESSINGER, Silvio. Hermeto Pascoal inédito na Internet. Cybernotas. (Artigo publicado em 8 de novembro, 2000). In: www. cliquemusic.uol.com.br (Acesso em 7 de janeiro, 2009).

Hermeto Pascoal inédito na Internet. Cybernotas. (Artigo publicado em 8 de novembro, 2000). In: www.cliquemusic.uol.com.br (Acesso em 7 de janeiro, 2009).

GAIA, Zélia. Querido Hermeto (Carta a Hermeto Pascoal). Palmeira dos índios: manuscrito, 2003. In: O Menino Sinhô, vida e música de Hermeto Pascoal para crianças. Texto de Edmiriam Módolo Villaça. Ilustrações de Rosinha Campos. Carta de Zélia Gaia. São Paulo: Ática, 2007.

GILMAN, Bruce. Sorcerer's apprentice. sem data. In: Brazzil Magazine. 2009 (www.brazzil.com/musdec96.htm, acesso em 10 de janeiro, 2009).

GONTIJO, Murilo. Minha religião é a música. Boletim informativo da UFMG. n.1285, ano 26, 19 de julho de 2000. p.5. In: www.ufmg.br/boletim/bol1285 (Acesso em 7 de janeiro, 2009).

IVANOV, Ricardo. Hermeto Pascoal cobra nova vida da MPB. 16 de setembro, 2002. In: www.terra.com.br/musica (Acesso em 21 de janeiro, 2009).

JOBIM, Antônio Carlos. Cancioneiro Jobim, 1971-1982. v.4. Músicas de Tom Jobim, arranjos de Paulo Jobim, texto de Sérgio Augusto, apresentação de Paulo Jobim, desenhos de Elizabeth Jobim, tradução de Paulo Henriques Britto. Rio de Janeiro: Jobim Music/Casa da Palavra, 2000.

JOBIM, Paulo. Apresentação. In: Cancioneiro Jobim, 1971-1982. v.4. Músicas de Tom Jobim, arranjos de Paulo Jobim, texto de Sérgio Augusto, apresentação de Paulo Jobim, desenhos de Elizabeth Jobim, tradução de Paulo Henriques Britto. Rio de Janeiro: Jobim Music/Casa da Palavra, 2000.

KRICH, John. Why is this country dancing?: a one-man samba to the beat of Brazil. New York: Simon \& Schuster, 1993.

LOUREIRO, Mônica. Uma celebração da sanfona. Cybernotas. (Artigo publicado em 3 de julho, 2001). In: www.cliquemusic. uol.com.br (Acesso em 7 de janeiro, 2009).

MARCONDES, Marco Antônio (Org.) Encilopédia da música brasileira: popular, erudita e folclórica. 2ed. São Paulo: Art Editora / Publifolha, 1998.

McGOWAN, Chris; PESSANHA, Ricardo. The Billboard book of Brazilian music: samba, bossa nova, and the popular sounds of Brazil. Prefácio de Paul Winter. New York: Bilbosard Books, 1991.

MILLARCH, Aramis. Abertura (Opus 5). Tablóide digital. In: www.millarch.org. 1975 (Acesso em 21 de janeiro de 2009; publicado anteriormente no Estado do Paraná, 6 de fevereiro de 1975, p.4).

A Volta dos filhos prodígios. Tablóide digital. In: www.millarch.org. 1980a (Acesso em 21 de janeiro de 2009; publicado anteriormente no Estado do Paraná, 21 de agosto de 1980, p.10). 
Abertura (Opus 5). Tablóide digital. In: www.millarch.org. 1979 (Acesso em 21 de janeiro de 2009; publicado anteriormente no Estado do Paraná, 15 de abril de 1979, p.1).

Instrumentistas. Tablóide digital. In: www.millarch.org. 1980b (Acesso em 21 de janeiro de 2009; publicado anteriormente no Estado do Paraná, Jornal da Música, 16 de novembro de 1980, p.30).

Na época do vídeo, poeta Emílio ressurge na tela. Tablóide digital. In: www.millarch.org. 1986 (Acesso em 21 de janeiro de 2009; publicado anteriormente no Estado do Paraná, Caderno Almanaque, 5 de abril de 1986, p.23).

0 Som da gente em terra de Marlboro (os bastidores). Tablóide digital. In: www.millarch.org. 1989c (Acesso em 10 de fevereiro de 2009; publicado anteriormente no Estado do Paraná, Caderno Almanaque, 15 de março de 1989, p.3).

0 Som da gente em terra de Marlboro. Tablóide digital. In: www.millarch.org. 1989b (Acesso em 21 de janeiro de 2009; publicado anteriormente no Estado do Paraná, Caderno Almanaque, 14 de março de 1989, p.3).

Som contemporâneo. Tablóide digital. In: www.millarch.org. 1977 (Acesso em 21 de janeiro de 2009; publicado anteriormente no Estado do Paraná, Jornal da Música, 3 de julho de 1977, p.29).

Também deu no NYT: o elogio ao som da gente. Tablóide digital. In: www.millarch.org. 1989a (Acesso em 21 de janeiro de 2009; publicado anteriormente no Estado do Paraná, Caderno Almanaque, 22 de março de 1989, p.3).

Uma geral do múltiplo talento de Miles Davis. Tablóide digital. In: www.millarch.org. 1988 (Acesso em 21 de janeiro de 2009; publicado anteriormente no Estado do Paraná, Caderno Almanaque, Música, 9 de outubro de 1988, p.23).

MORENA, Aline. Cannon do Slaves Mass e artigo sobre Hermeto. E-mail de Aline Morena a Fausto Borém em 7 de março de 2009.

MORENA, Aline, Ed. Princípios da Música Universal criada por Hermeto Pascoal. Partituras. Curitiba: 30 de setembro de 2008. In: www.hermetopascoal.com.br (Manuscrito escaneado, acesso em 7 de janeiro, 2009).

MORENA, Aline; PASCOAL, Hermeto. Chimarrão com rapadura. 2009a. In: www.hermetopascoalealinemorena.com.br. (Acesso em 9 de janeiro, 2009).

Correções sobre a "Linha do Tempo" do livro "O Menino Sinhô", lançado pela editora Ática. Partituras. 2009b. In: www.hermetopascoal.com.br (e-mail de Edmiriam Módolo Villaça para Aline Morena e Hermeto Pascoal. Acesso em 7 de janeiro de 2009).

Correções sobre a "Linha do Tempo" do livro "0 menino Sinhô": segunda parte. Partituras. 2009c. In: www.hermetopascoal.com.br. (e-mail de Edmiriam Módolo Villaça para Aline Morena e Hermeto Pascoal. Acesso em 7 de janeiro de 2009).

. O som nosso de cada um. 2009d. In: www.hermetopascoalealinemorena.com.br. (Acesso em 9 de janeiro, 2009).

MOUJÁN, Pedro Fernández. Otra noche "hermética" en Buenos Aires. La Capital, el diario del Mar del Plata. 11 de outubro, 2007. In: www.lacapitalnet.com.ar. (Acesso em 9 de janeiro, 2009).

SANTOS NETO, Jovino. Re: Cannon do Slaves Mass. (e-mail de Jovino Santos Neto a Fausto Borém em 16 de janeiro de 2009). PASCOAL, Hermeto. Agenda. In: www.hermetopascoal.com.br. 2009a (Acesso em 9 de janeiro, 2009).

Amor, paz e esperança. In: www.hermetopascoal.com.br. 1980. (Partitura editada disponibilizada no site do compositor, acesso em 9 de janeiro, 2009).

Biografia. In: www.hermetopascoal.com.br. 2009b (Acesso em 9 de janeiro, 2009).

Calendário do Som. Ed. A. P. Quartim de Moraes. Apresentação de Sérgio Cabral. São Paulo: Editora Senac, 2000 a.

Cannon. In: Slaves Mass. Hermeto pascoal (flauta e voz) com participações vocais de Flora Purim, Airto Moreira,

Hugo Fattoruso, Raul de Souza e Laudir de Oliveira. WEA/Warner: BS2980, 1977. (LP)

Discografia. In: www.hermetopascoal.com.br. 2009c (Acesso em 9 de janeiro, 2009).

Licenciamento. In: www.hermetopascoal.com.br. 17 de novembro, 2008. (Acesso em 10 de fevereiro, 2009).

0 Ovo. 15 de setembro, 2008. Partituras. In: www.hermetopascoal.com.br. (Partitura manuscrita disponibilizada no site do compositor, acesso em 9 de janeiro, 2009).

Prefácio do Calendário do Som. Ed. A. P. Quartim de Moraes. Apresentação de Sérgio Cabral. São Paulo: Editora Senac, $2000 b$.

PASCOAL, Hermeto; BORÉM, Fausto. Cannon (dedicada a Cannonball Adderley) para flauta, humming na flauta e sons prégravados. Partitura transcrita por Hermeto Pascoal e editada por Fausto Borém a partir da gravação do compositor no disco Slave mass (1977). Per Musi, n.22. Belo Horizonte: UFMG, 2010. p.80-82.

PASCOAL, Hermeto; PEREIRA, Ruy. Cannon (dedicada a Cannonball Adderley). Partitura transcrita por Hermeto Pascoal e desenhada por Ruy Pereira na capa interna do disco Slave mass. WEA/Warner: BS2980, 1977. (LP)

PAULA, Aluísio de. A música é branca. Notícias. In: www.hermetopascoal.com.br. 7 de agosto, 2007. (Acesso em 10 de janeiro, 2009).

PRADINES, César. Música brasileña en pareja. La Nacion. Espetáculos. 13 de maio, 2006. In: www.lanacion.com.ar. (Acesso em 10 de janeiro, 2009).

PRANDINI, José Carlos. Um estudo da improvisação na música de Hermeto Pascoal: transcrição e análise de solos improvisados. Campinas: UNICAMP, 1996. (Dissertação de Mestrado) 
PURIM, Flora. Este desenho... In: Slaves Mass. 1977 (Texto de apresentação do LP WEA 36.021).

RAMOS, Bernardo. Glossário universal. In: www.itibereorquestrafamilia.com.br. 2009 (Acesso em 20 de janeiro, 2009).

ROBINSON, N. Scott. Rhythm legend Airto: then \& now. Modern Drummer. v.24, n.6, June, 2000, p.68-82. In: http://www.nscottrobinson.com/airto.php (Acesso em 10 de janeiro, 2009).

RODRIGUES, Késia Decoté. Música popular instrumental brasileira (1970-2005): uma abordagem subsidiada pelo estudo da vida e obra de oito pianistas. Rio de Janeiro: UFRJ, 2006 (Dissertação de Mestrado).

RODRIGUES, Otávio. Hermeto. Vida simples. Dezembro, 2003. In: www.vidasimples.abril.com.br (Acesso em 12 de janeiro, 2009).

SANDRONI, Carlos. O Feitiço decente: transformações do samba no Rio de Janeiro.

Rio de Janeiro: Editora Jorge Zahar, 2001.

SIQUEIRA, José. Sistema Modal na música folclórica do Brasil. João Pessoa: Secretaria de Educação e Cultura / Diretoria Geral de Cultura, 1981.

SIVUCA. Quando conheci o Hermeto. In: Calendário do Som. Ed. A. P. Quartim de Moraes. Apresentação de Sérgio Cabral. São Paulo: Editora Senac, 2000 (contra-capa).

SCHOENBERG, Arnold. Funções Estrururais da Harmonia. Trad. Eduardo Seincman, Ed. Leonard Stein. São Paulo: Via Lettera, 2004 [1969].

Exercícios Preliminares em Contraponto. Trad. Eduardo Seincman, Ed. Leonard Stein. São Paulo: Via Lettera, 2001 [1963]. Harmonia. Trad. Marden Maluf. São Paulo: Editora UNESP, 1999 [1911].

SIXPACK, Joe. Guide to Brazilian music. In: www.slipcue.com (Acesso em 10 de janeiro, 2009).

TABORDA, Pretextato. Música de Invenção. Rio de Janeiro: UNIRIO, 1998. (Dissertação de mestrado).

TÁRIK DE SOUZA. Hermeto Paschoal. In: Autores e intérpretes. 9 de dezembro, 1990 (www.sescsp.org.br/sesc/hotsites/mpb5; acesso em 9 de fevereiro de 2009)

TINÉ, Paulo José de S. A Harmonia no Contexto da Música Popular - Um Paralelo com a Harmonia Tradicional. Revista Internacional VIDETUR-LETRAS 6. Editora Mandruvá, 2002. Disponível na Internet :<www.hottopos.com/vdletras6/TINÉ.htm>.

VILLAÇA, Edmiriam Módolo. O Menino Sinhô, vida e música de Hermeto Pascoal para crianças. Ilustrações de Rosinha Campos. Carta de Zélia Gaia. São Paulo: Ática, 2007.

WISNIK, José Miguel. 0 minuto e o milênio ou por favor professor, uma década de cada vez. In: Anos 70: 1 - Música popular. Org. Adauto Novaes. Rio de Janeiro: Europa, 1979-1980.

ZWARG, Itiberê. A música universal. In: www.itibereorquestrafamilia.com.br. 2009a (Acesso em 20 de janeiro, 2009).

Cifragem universal. In: www.itibereorquestrafamilia.com.br. 2009b (Acesso em 20 de janeiro, 2009).

Relese 07: Compor de corpo presente. In: www.itibereorquestrafamilia.com.br. 2009c (Acesso em 20 de janeiro, 2009).

Calendário do som. Itiberê Zwarg e Itiberê Orquestra Família. Gravadora Maritaca, 2005 (CD duplo).

Fausto Borém é Professor Titular da Escola de Música da Universidade Federal de Minas Gerais (UFMG), onde criou o Mestrado em Música e a Revista Per Musi. É pesquisador do CNPq desde 1994 e seus resultados de pesquisa incluem um livro, três capítulos de livro, dezenas de artigos sobre práticas de performance e suas interfaces (composição, análise, musicologia, etnomusicologia e educação musical) em periódicos nacionais e internacionais, dezenas de edições de partituras e apresentação de recitais nos principais eventos nacionais e internacionais do contrabaixo. Recebeu diversos prêmios no Brasil e no exterior como solista, teórico, compositor e professor. Acompanhou músicos eruditos como Yo-Yo Ma, Midori, Menahen Pressler, Yoel Levi, Fábio Mechetti, Luiz Otávio Santos, Arnaldo Cohen, Antônio Menezes e músicos populares como Hermeto Pascoal, Egberto Gismonti, Henry Mancini, Bill Mays, Kristin Korb, Grupo UAKTI, Toninho Horta, Juarez Moreira, Tavinho Moura, Roberto Corrêa, Maurício Tizumba e Túlio Mourão. Suas gravações incluem o CD Brazilian Music for the Double Bass, o CD e DVD O Aleph de Fabiano Araújo Costa, os CDs da Orquestra Barroca do Festival Internacional de Juiz de Fora de 2005 a 2009 (com Luiz Otávio Santos), a Suite for Flute and Jazz Piano de Claude Bolling (com Maurício Freire, Tânia Mara e Eduardo Campos) e No Sertão (com o violista Roberto Corrêa) e Cidades Invisíveis (com o saxofonista Daniel d'Olivier).

Fabiano Araújo é Mestre em Música pela Escola de Música da UFMG e Bacharel em Música Popular pelo Centro de Artes da UNICAMP. Foi professor da FAMES (Faculdade de Música do Espírito Santo) Atualmente é Professor Assistente do Centro de Artes da Universidade Federal do Espírito Santo (UFES), onde leciona Harmonia, Estruturação, Improvisação e Teclado. Lançou em 2007 o CD e DVD O Aleph, alcançando cotação máxima de crítica do Jornal O Globo. Seu novo trabalho de interpretação de nove peças do Calendário do Som de Hermeto Pascoal foi gravado e publicado em Portugal, com a participação do contrabaixista norueguês Arild Andersen do baterista Alexandre Frazão (Brasil/Portugal) e do saxofonista Guto Lucena (Brasil/Portugal). 